\title{
LARACHEY LA MAMORA: DOS FORTIFICACIONES ESPAÑOLAS EN TIEMPOS DE FELIPE III
}

Francisco Javier Bueno Soto

\section{INTRODUCCIÓN}

La monarquía española, atrapada durante la primera mitad del reinado en las guerras de Flandes, había conseguido que la política pacifista del duque de Lerma diera su fruto con la firma de una tregua en 1609 - la de los Doce Años-que unido a la anterior paz firmada en 1604 con la Inglaterra del recién instaurado Jacobo I, le permitió tener las manos libres para afianzarse en dos puertos clave de la fachada atlántica marroquí. Larache, anhelada siempre por Felipe II, pero que jamás pudo conseguir ante la firme pero flexible política de al-Mansur, sin duda el mejor representante de la dinastía saadí; y La Mamora, magnífico puerto un poco más al sur, en la desembocadura del río Sebú, cuyo estuario hervía de navíos corsarios de varias procedencias, entre ellos marroquíes, moriscos hornacheros y granadinos, holandeses e ingleses (Fig. 1).

\section{LARACHE}

Las disensiones entre los hijos de al-Mansur -máximo representante de la dinastía saadí ${ }^{-}$- propiciaron que la ciudad llegara a manos españolas sin ne-

1. Al-Mansur (elVictorioso), también llamado «al-Dhahabi», es decir, el Dorado, debido a sus conquistas en el Sudán de donde importó gran cantidad de oro a Marruecos. Subió al trono tras la batalla de Alcazarquivir -importantísima también para los destinos de España, pues en ella murió el rey don Sebastián de Portugal, lo cual propició la incorporación del inmenso imperio portugués a la corona española- y podemos considerarlo como el más grande monarca de la dinastía saadí. Fue también un monarca capital en el terreno de la fortificación moderna, sobre todo por sus actuaciones en Larache y Fez. Para el conocimiento de las fortificaciones saadíes en esta última ciudad es obligado consultar los trabajos de Montaser LAOUKILI, Arqueólogo-Conservador y director adjunto del Musée Palais Bathae de Fès, autor asimismo de una magnífica ponencia en este Congreso: «Borj Nord y Bordj Sud: Las fortificaciones saadianas de Fez». 


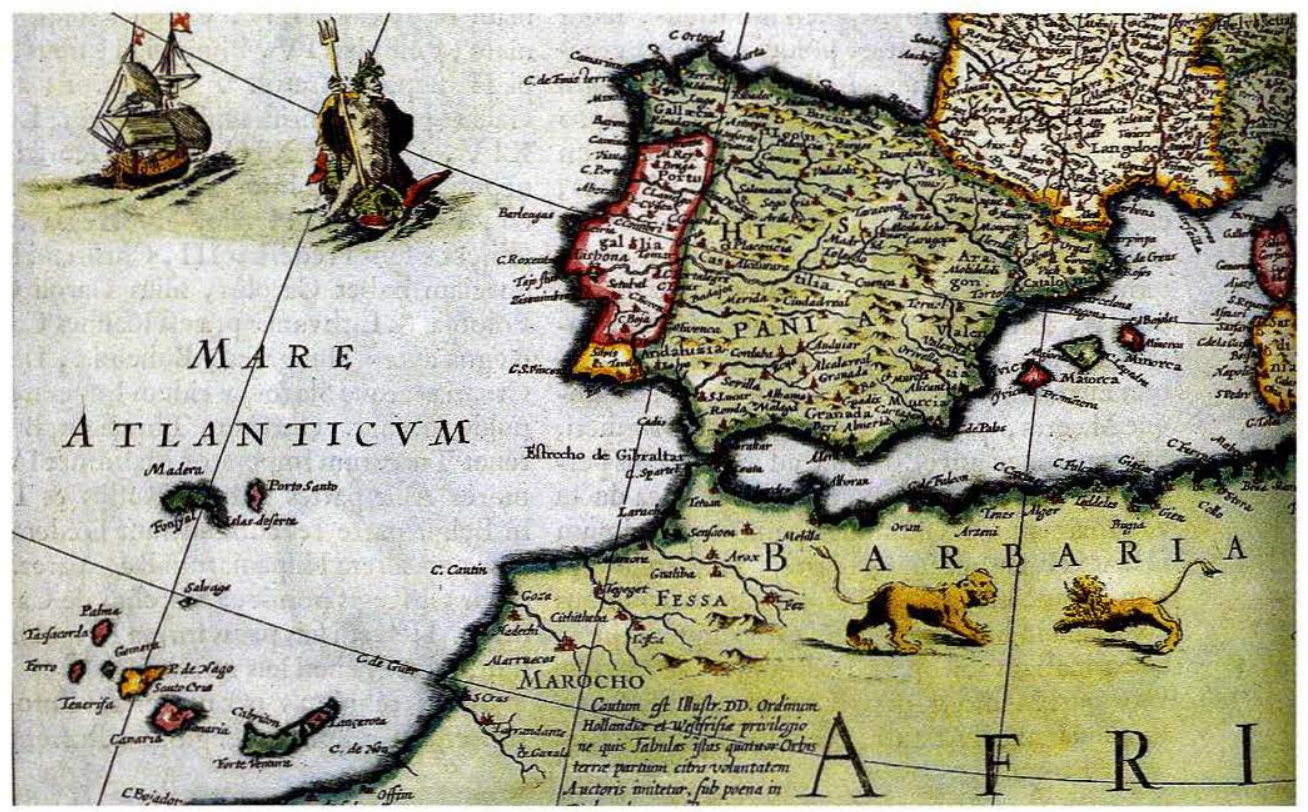

Fig. 1: Guilielmo Blaeu, «Evropa recens descripta» (detalle), en Joan blaeu, Atlas Maior, (Ámsterdam, 1665).

cesidad de disparar un solo arcabuzazo. Muley Xeque, el mayor de ellos, sultán de Fez, necesitaba urgente ayuda para la guerra que mantenía con sus otros hermanos, Muley Cidán y Abú Faris, que le era muy desfavorable. Para ello viajó a la corte de Felipe III y pactó con el soberano español la cesión a España de Larache a cambio de que previamente se le trasladara a Marruecos con una valija de 6.000 arcabuces y 200.000 ducados que le permitieran organizar de nuevo la guerra contra su hermano Cidán². Una vez en Marruecos, Muley Xeque se las arreglaría para que la guarnición de Larache no ofreciera ninguna resistencia a la armada española ${ }^{3}$.

La ocupación de la ciudad se llevó a cabo el 20 de noviembre de 1610 a manos del marqués de San Germán (Fig. 2). Un día después comenzó el reconocimiento

2. Su otro hermano, Abu Faris, había muerto asesinado en 1608. Vid. GARCÍA FIGUERAS, Tomás y Carlos RODRÍGUEZ JOULIA, Larache, datos para su historia en el siglo XVII, Instituto de Estudios Africanos, CSIC, Madrid, 1973, pág. 45.

3. Archivo General de Simancas (en adelante AGS), Estado, leg. 2638. Recoge el tratado que el 9 de septiembre de 1609 se firmó entre Muley Xeque y Felipe III para la entrega de Larache a España. 


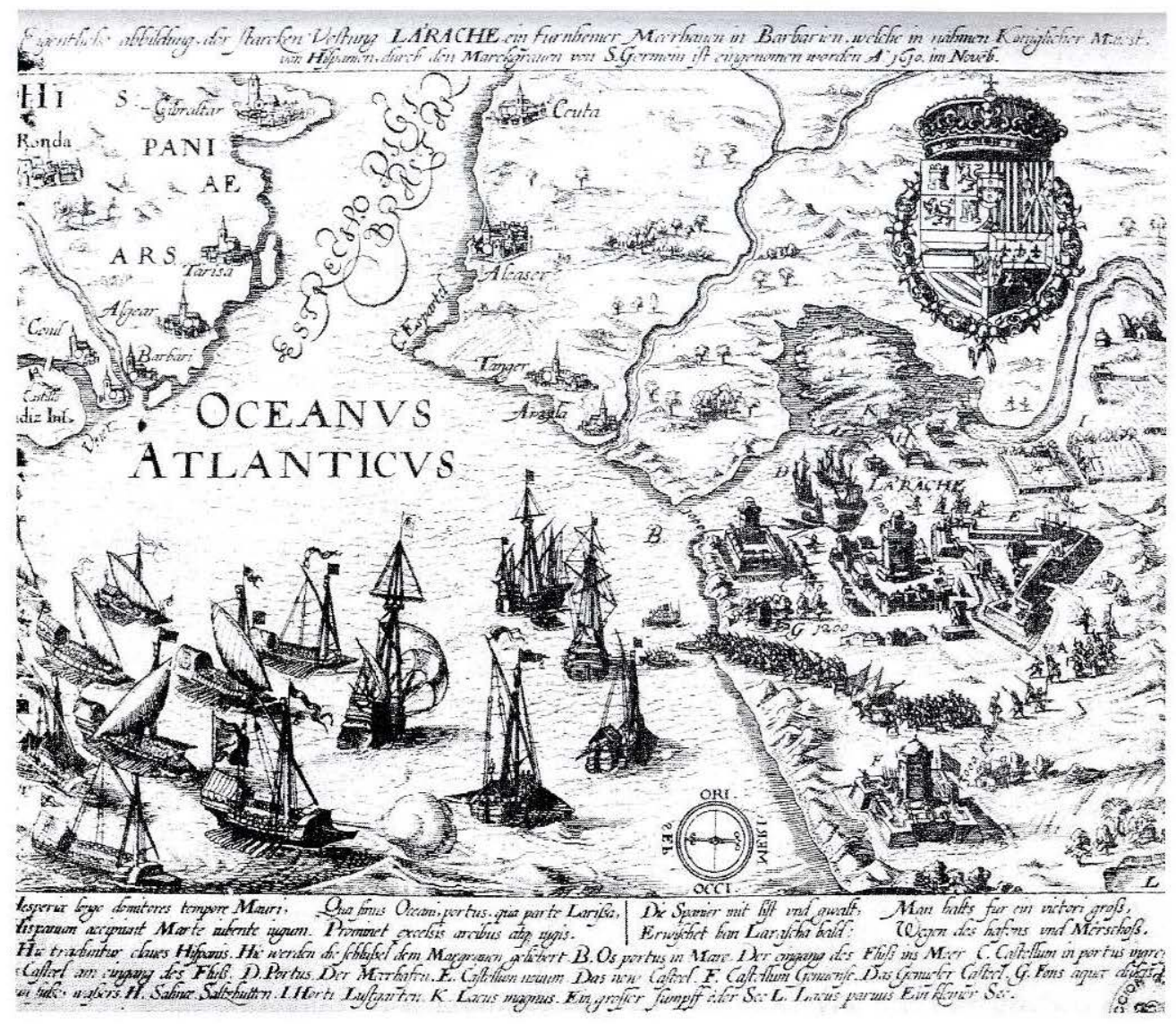

Fig. 2: Ocupación de Larache, grabado alemán del siglo XVII, Copia de Francisco Manuel de Mena. Biblioteca del Palacio Real de Madrid, IX-M.-153, grabado n ${ }^{\circ} 380$.

del estado de las fortificaciones y de todo el enclave del que ya podemos denominar «presidio» ${ }^{4}$ español. Bautista Antonelli, fue el ingeniero encargado de «poner en defensa», como se decía entonces, la plaza militar. Sería su último encargo, pues tras solicitar su baja en repetidas ocasiones por sus muchos años y enfermedades, le fue concedida en 1615. Apenas un poco después -11 de febrero de 1616--murió en Madrid ${ }^{5}$.

4. Sebastián de COVARRUBIAS en su Tesoro de la Lengua Castellana o Española (1611) define así el término: «Del nombre latino presidium... Comúnmente llamamos presidio el castillo o fuerça donde ay gente de guarnición».

5. ANGULO IÑIGUEZ, Diego, Bautista Antonelli: las fortificaciones americanas del siglo XVII, Madrid, Hauser y Menet, 1942, pág. 82. 
Perteneciente a una familia de famosos ingenieros de raigambre italiana que siempre trabajaron para la monarquía española, su hermano mayor, Juan Bautista, se hizo célebre por su proyecto de navegación del Tajo en tiempos de Felipe II. Importante era el concepto que este Juan Bautista Antonelli, el Mayor, tenía sobre lo que debían ser las defensas fortificadas de la monarquía, sobre todo muy ilustrativo en cuanto a los presidios que estudiamos: En un informe sobre las fortificaciones de los reinos de Felipe II en 1569, tras comparar la Monarquía Hispánica con los grandes imperios históricos -se remontaba hasta los asirios-, decía que era menester «cerrar la costa como una muralla, haziendo cuenta que los lugares de ella sean baluartes, los puertos sean las puertas, y las torres las garitas o atalayas» y que el rey de España «dexava a España la mar por fosso y por adarves las fronteras que hauía ganado en Berbería y los reynos que tenía en Italia» ${ }^{6}$. Pues bien, Bautista Antonelli, segundo de la saga, tenía ya por los años de la cesión de Larache una acreditadísima carrera militar. Había estado trabajando en Navarra y el levante peninsular (en Peñíscola, Alicante y Cartagena). Con su hermano mayor ayudó en las fortificaciones de Orán y Mazalquivir y visitó el puerto de Melilla. Pero donde Bautista Antonelli destacó con más fuerza en sus proyectos como ingeniero fue en América. Allí intervino en las trazas del castillo del Morro de La Habana, en la fortificación de Portobelo, san Juan de Ulúa, san Juan de Puerto Rico y, sobre todo, en el plan de defensa y fortificación de Cartagena de Indias. Trabajó también en el proyecto de defensa del estrecho de Magallanes, donde propuso el levantamiento de dos fuertes para control del paso corsario inglés ${ }^{7}$.

En la costa norte de Marruecos, en su fachada atlántica, apenas $150 \mathrm{~km}$ en línea recta al sur de Cádiz, yace Larache junto a la desembocadura del Lucus, muy cerca de la Lixus romana, «a treinta y cuatro grados de altura del Polo poco más o menos», según la latitud dada por Bautista Antonelli ${ }^{8}$. Es la «Alarache» de las fuentes españolas del siglo XVII, y más propiamente la al-Aaraix árabe, plural de Araix que

6. AGS, Guerra Antigua, leg. 72, fols. 294 y 295, citados por CÁMARA MUÑOZ, Alicia, Fortificación y ciudad en los reinos de Felipe II, Nerea, Madrid, 1998, págs. 61 y 69. Esta obra de la Doctora Cámara es, sin duda, de referencia. La autora está considerada por la totalidad de los especialistas internacionales como la máxima autoridad mundial en arquitectura militar española de la Edad Moderna.

7. AGS, Guerra Antigua, leg. 580, fol. 257. Consulta del Consejo de Indias de 18 de abril de 1601 donde se resume la trayectoria como ingeniero de Bautista Antonelli.

8. AGS, Guerra Antigua, leg. 744, s. fol. Cuenta Antonelli en la relación ya citada anteriormente, que dirige al rey el 10 de diciembre de 1610, apenas unos días después que Muley Xeque entregara la ciudad a Felipe III, que «está Alarache en treinta y quatro grados de altura del polo, poco más o menos, en la costa de África del mar océano. Corre la dicha costa de norte a sur empezando del cabo de Espartel que está doçe leguas de aquí». 
significa «parra» o, mejor aún, sitio cubierto por una o varias parras donde se pasaba la tarde; lugar placentero.

León Africano en su magnífica Descripción de África nos cuenta a principios del siglo XVI, que antiguamente, «en los tiempos en que Arcila y Tánger eran de los moros», estaba muy densamente poblada, pero que luego, una vez estas ciudades en poder de los cristianos, Larache fue despoblada por temor de sus habitantes a los portugueses, aunque esa situación sólo duró unos veinte años, ya que el rey de Fez mandó repoblarla y fortificarla para evitar la tentación lusitana de apoderarse de ella. Añade el Africano que la ciudad tenía un puerto muy difícil para el que quisiera penetrar por la boca del río y que en las cercanías de la ciudad había gran cantidad de pantanos ricos en angulas y aves de agua. También nos habla de la abundancia de «espesos bosques cerca de las riberas del río», que si bien sirven de guarida a numerosas fieras, proporcionan a sus moradores materia prima para hacer carbón, que producen en grandes cantidades y lo envían a Tánger y Arcila9 ${ }^{9}$.

Bautista Antonelli anota en su relación de marzo del año siguiente, tres meses después de que la plaza pasara a España, que Larache cuando se entregó era lugar de cien vecinos, aunque la mayoría se encontraban fuera, si bien a poca distancia. Dentro del recinto había no más de sesenta casas «todas cubiertas de yerba», de estructura muy sencilla, agrupadas entre dos pequeños castillos, predominantemente al oeste y al sur del más interior, con una pequeña mezquita que más adelante se reedificaría para pasar a ser el convento de San Francisco e iglesia de la fuerza. La cerca que las circundaba era de poca enjundia con bastantes desperfectos por el abandono de sus habitantes y de fábrica muy mala «la mayor parte de piedra y barro, y algunos pedaços caydos» ${ }^{10}$. Es la muralla medieval de Larache, la muralla con cubos semicirculares que ceñía el recinto de la Qasba ${ }^{11}$.

El castillo del frente de tierra, es decir, el que protegía la retaguardia de la villa situado más al interior, construido por al-Mansur, ya citado, contaba el día de

9. LEÓN AFRICANO, Juan, De la descripción de África y de las cosas notables que en ella se encuentran, (Venecia, 1550), edición crítica y traducción del original italiano por Luciano RUBIO, prólogo de Amin MAALOUF, Madrid, ed. Muley-Rubio, 1999, pág. 155.

10. AGS, Guerra Antigua, leg. 744, s. fol. «Relación del sitio de Alarache en la Costa de Beruería en el Mar oçeano», dada por Bautista Antonelli. Larache, 28 de marzo de 1611.

11. ELBOUDJAY, Abdelatif, «Larache: Estudio de historia y arqueología urbana y monumental», Tesis Doctoral, Universidad de Rabat, 1999, pág. 109. 
la entrega del enclave a Felipe III con 60 cañones de hierro colado, y fue bautizado con el nombre de castillo de Nuestra Señora de Europa en honor de la fiesta de la Presentación de Nuestra Señora que se celebraba en esa misma fecha, aunque posteriormente las fuentes suelen referirse a él también con el nombre de castillo de Santa María. Al otro fuerte, con treinta cañones, se le llamó de San Antonio, santo titular de muchas fortalezas y baluartes por ser símbolo de resistencia, ya que él aguantó las tentaciones de muchos diablos con quienes mantuvo continua lucha.

El 16 de noviembre de 1611, Bautista Antonelli envió al Consejo de Guerra un plano general de Larache y sus alrededores (Fig. 3) junto a una relación firmada también por el maestre de campo Gaspar de Valdés ${ }^{12}$. En el plano figuran la trincheras que unen a los dos castillos, las torres que se han de hacer para vigilancia y guarda de los pastos del ganado, de las huertas, de la entrada del puerto y

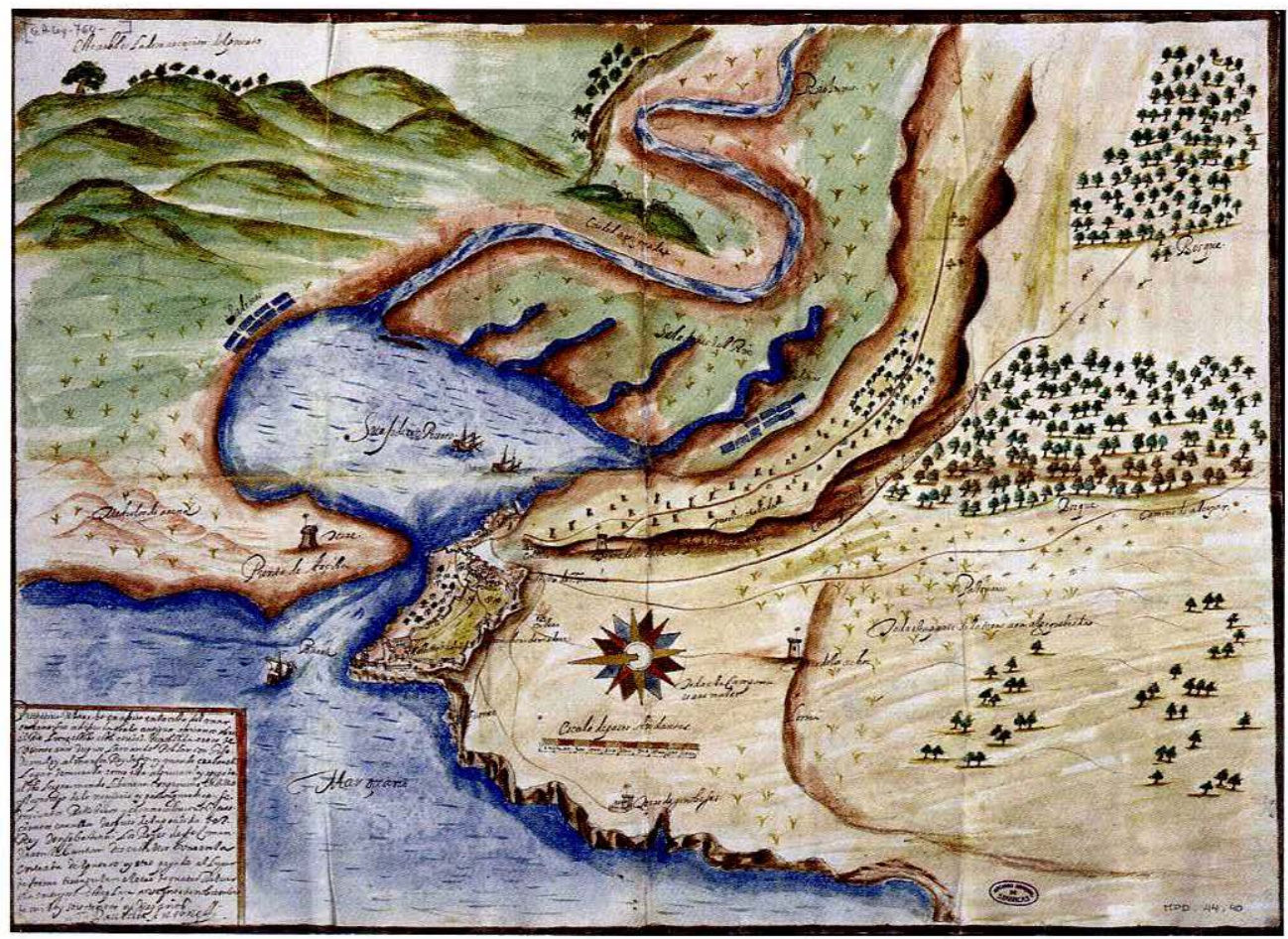

Fig. 3: Juan Bautista Antonelli. Plano de Larache y sus alrededores. Archivo General de Simancas, MPD, 44, 40.

12. AGS, Guerra Antigua, leg. 760 , s. fol. «Relación de donde está la leña para las caleras y la distançia que ay, y la orden que se á de tener en traerla.Y de las torres que es neçesario que se hagan para guardia de la campaña y del ganado». 
-muy importante- de los leñadores que trasportaban la leña para las caleras y la fajina para los terraplenos desde los bosques de alcornocales. Estos aparecen representados en la margen derecha del Lucus, sobre el camino de Alcázar (Alcazarquivir). Junto al mar, en la parte sur o de La Mamora, una torre preexistente a la llegada de los españoles, la llamada de los Genoveses. También se señala la barra del río y tras ella el puerto o surgidero con dos navíos fondeados. Las dunas, las salinas y río arriba, de una forma esbozada, el perfil de lo que Antonelli rotula como «çiudad arruynada», que no es otra que la antigua ciudad púnico-romana de Lixus.

La constatación que hace Antonelli en la cartela inferior izquierda del plano de que los castillos fueron construidos tras la batalla de Alcazarquivir, es un dato más que abunda en la atribución que se viene haciendo al gran rey saadí Muley al-Mansur de haber sido él quien mandara construirlos (Fig. 4, detalle). No sabemos nada, sin embargo, del ingeniero o ingenieros -si es que hubo alguno- autor de las trazas de ambos; si fue una sola persona o varias; cuál su nacionalidad; cuál su nivel profesional.

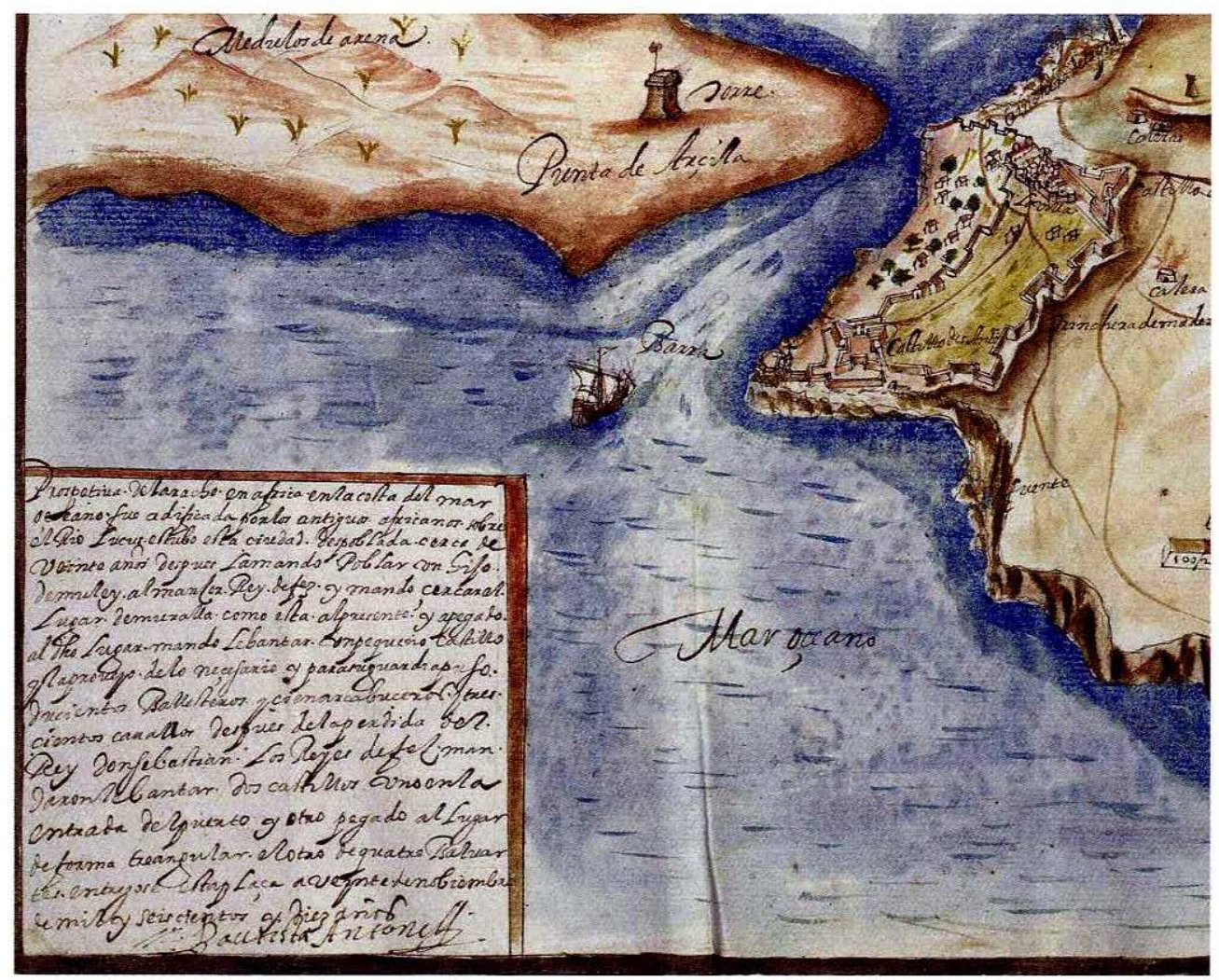

Fig. 4: Juan Bautista Antonelli. Plano de Larache y sus alrededores (detalle). Archivo General de Simancas, MPD, 44, 40. 
¿Ingeniero? ¿Maestro mayor? ¿Entretenido de ingeniero? Hay quien ha especulado con la autoría de prisioneros portugueses tras Alcazarquivir, lo cual entraría dentro de lo bastante probable, dada la gran cantidad que hubo de ellos y la indudable factura europea de ambas construcciones ${ }^{13}$.

Pero lo que sí podemos afirmar con rotundidad son las características algo anacrónicas de ambas estructuras. En efecto, la forma geométrica de sus plantas, triangular en un caso y cuadrangular en el otro, ya no estaba bien vista por la mayoría de tratadistas, a no ser que el terreno no permita otro polígono con más lados. Las razones, fundamentalmente, para este descrédito del triángulo y del cuadrado son que los baluartes que con ellos hay que trazar resultan con un ángulo muy agudo, sobre todo en el caso de las plantas triangulares. El propio Antonelli se hace eco de ello cuando se refiere al castillo de Nuestra Señora de Europa: «Es de figura triangular todo, bóueda de poco sitio y por ser de tan mala figura como es la triangular no se le puede hazer ninguna fortificaçión y seruirse poco de sus murallas por ser los ángulos tan agudos» (Figs. 5 y 6). Y afirma que esta forma de fortificación «no se puede hacer si no es en sitio adonde no pueda hauer batería ni asalto y río en campaña rasa como ésta» ${ }^{14}$.

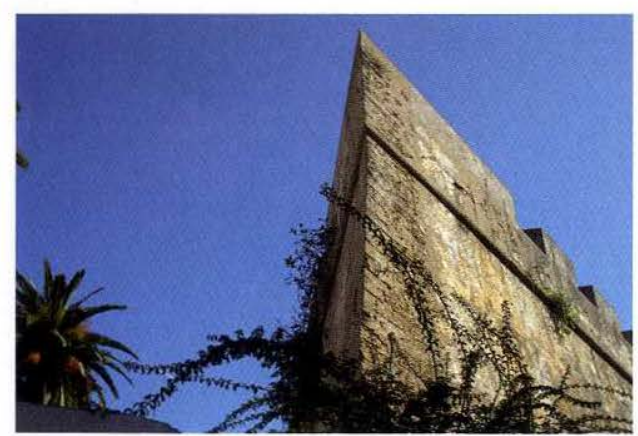

Fig. 5: Baluarte que mira al sureste del castillo de Santa María en una toma donde se aprecia su gran agudeza. Fotografía del autor.

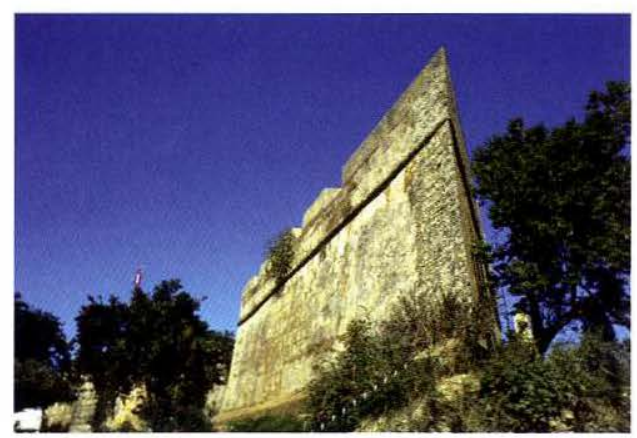

Fig. 6: Otra perspectiva del mismo baluarte del castillo de Santa María. Fotografía del autor.

Se refiere a él como «fortezuelo» y declara que está fabricado sin cimientos y que sus murallas excepto las esquinas son todas de tapial, es mala fábrica, por lo cual

13. GARCÍA FIGUERAS, Tomás, y Carlos RODRÍGUEZ JOULIA, op. cit., pág. 31.

14. AGS, Guerra Antigua, leg. 744, s. fol. «Relación sobre el sitio y fortificación de Alarache y memoria ansimismo de su ofensa i defensa», por Bautista Antonelli. Larache, 10 de diciembre de 1610. 


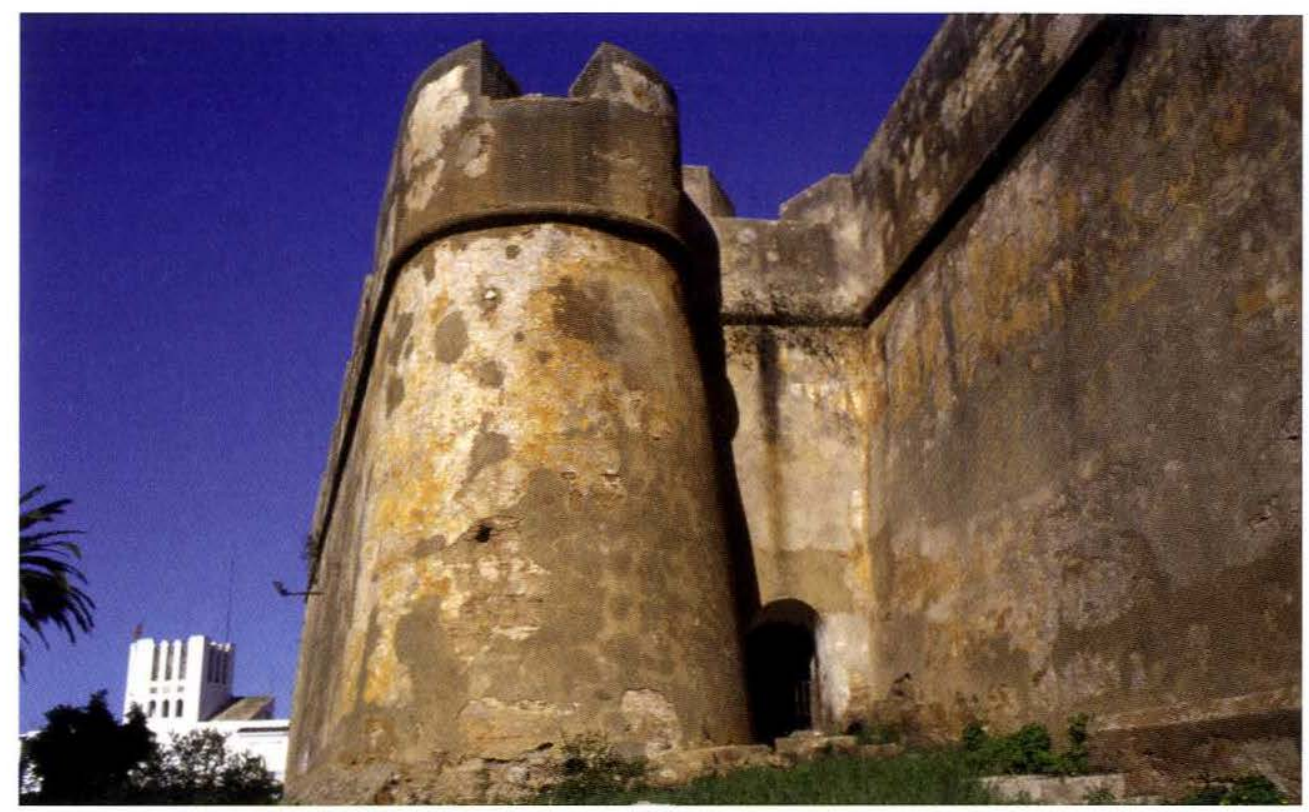

Fig. 7: Orejón del baluarte del suroeste, través (con su casamata) y parte de la cortina del frente de tierra del castillo de Santa María. Fotografía del autor.

no es posible hacer ninguna consideración del mismo (Fig. 7). Además, sus cortinas son sólo de bóvedas, careciendo de terrapleno, elemento que por entonces ya se había impuesto como indispensable para defender las espaldas de las cortinas.

Pasados unos meses, a finales de marzo de 1611, insiste Antonelli en la mala traza y fábrica de los dos castillos, especialmente del triangular, que se ha visto obligado «por fuerza» a incluirlo todo él en la fortificación que ha proyectado, ya que «no se puede abrazar con trabeses, quedando fuera ningún Baluarte del dicho castillo por ser los ángulos tan agudos» ${ }^{15}$.

El castillo de San Antonio no le ofrece tampoco buena opinión (Fig. 8). El cuadrado, si bien no tan acusadamente como el triángulo, tampoco permite obtener los baluartes con una punta lo suficientemente obtusa; asimismo le achaca la pequeñez de los mismos, y un mal foso que circundaba sólo la mitad del recinto, ya que la otra

15. AGS, Guerra Antigua, leg. 744, s. fol. «Relación del sitio de Alarache en la Costa de...» por Bautista Antonelli. Larache, 28 de marzo de 1611. 


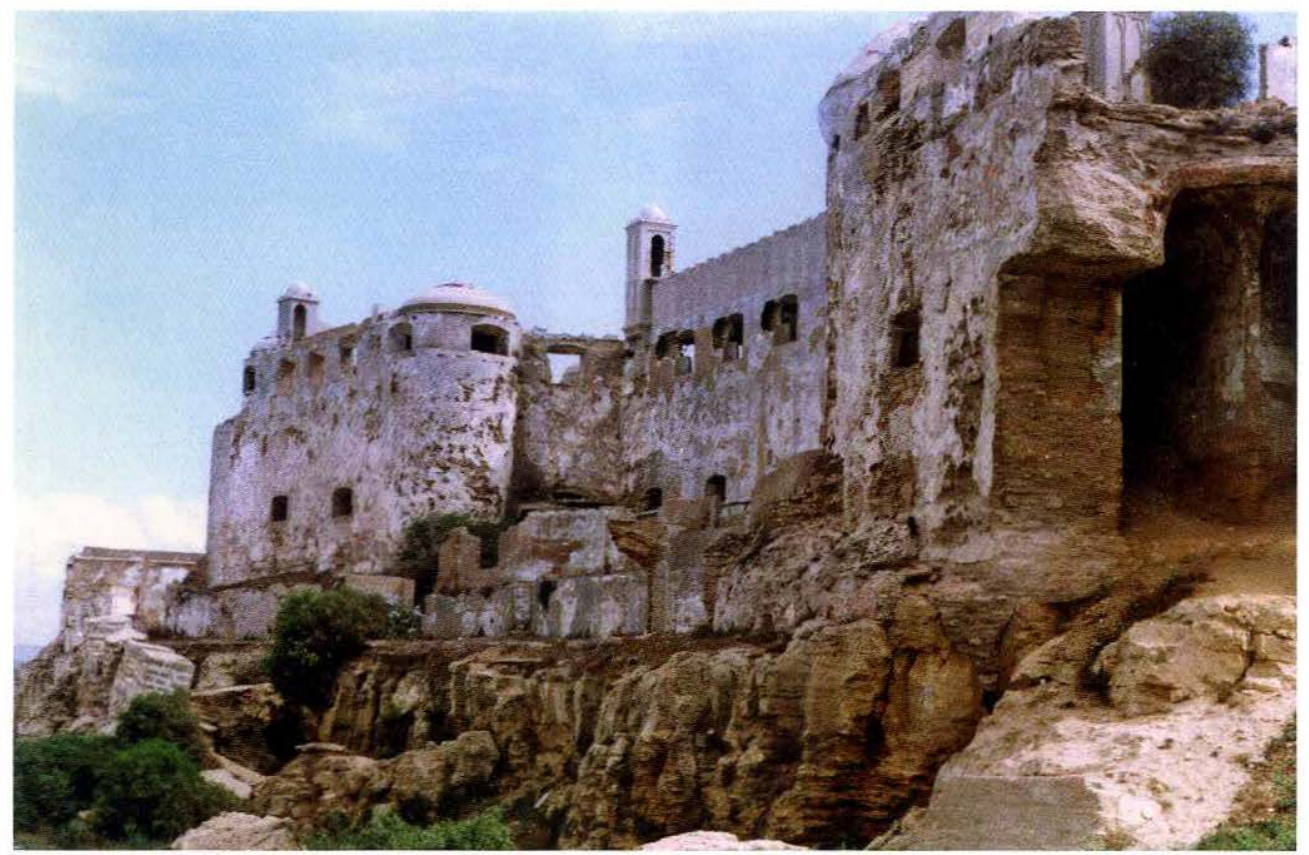

Fig. 8: El castillo de San Antonio en el año 2000. Fotografía cedida por Mohamed Sibari.

mitad estaba cercada con un pequeño reducto de tapiería. Advierte que, al igual que el de Nuestra Señora de Europa, el de San Antonio carece de terrapleno (Fig. 9), con la espalda de sus cortinas fabricadas sólo por bóvedas ${ }^{16}$ (Fig. 10).

Sin embargo, el reducto que había al pie del castillo, situado exactamente frente a la barra del río le merece mucha más consideración en lo que toca a la defensa de la entrada del puerto. Sólo sería necesario añadirle ocho o diez pies de altura a sus murallas y terraplenarlo para que la artillería «pueda jugar por barua [barba] de los parapetos» ${ }^{17}$. Aconsejaba sacar en un ángulo del reducto dos pequeños traveses que

16. AGS, Guerra Antigua, leg. 744, s. fol. «Relación del sitio de Alarache en la Costa...» por Bautista Antonelli. Larache, 28 de marzo de 1611.

17. AGS, Guerra Antigua, leg. 744, s. fol. «Relación sobre el sitio y fortificación de Alarache y memoria...», por Bautista Antonelli. Larache, 10 de diciembre de 1610. Se dice que la artillería actúa «a barba» o «a barbeta» cuando tira por encima del parapeto, hecho a propósito para ello, apoyadas las cañas de los cañones en el mismo, sin necesidad de cañoneras ni merlones. Según todos los ingenieros, para ello el parapeto no podía ser superior a tres pies de altura, unos $85 \mathrm{~cm}$. 


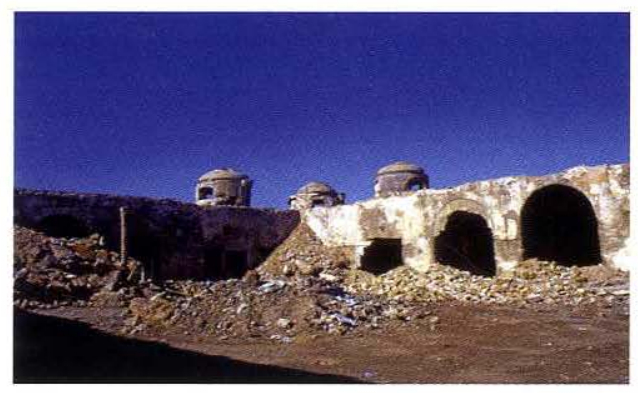

Fig. 9: Interior del castillo de San Antonio, actualmente en obras de restauración. Fotografía del autor.

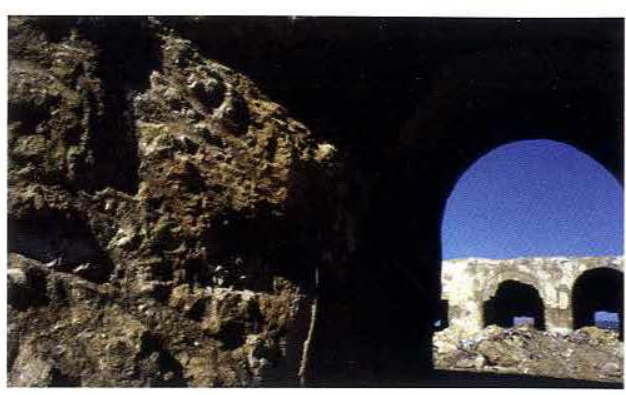

Fig. 10: Bóvedas del castillo de San Antonio. Fotografía del autor.

«limpiasen los lienzos», es decir, que desde ellos, se pudieran hacer disparos de flanqueo que guardaran las cortinas del reducto.

Pero sobre todo, la insistencia de Antonelli, su preocupación principal para poner Larache en defensa, consistía en la necesidad de abrazar los dos castillos con una muralla abaluartada que no sólo los uniera, sino que además, el castillo de Santa María quedara todo él englobado por un gran baluarte ${ }^{18}$. Así lo muestra en la planta con firma de 15 de marzo de 1612 (Fig. 11), enviada al rey por el gobernadorValdés, en la que va también sobrepuesta por una línea de puntos otra planta anterior del mismo Bautista Antonelli, todavía más espaciosa que esta, mucho más extendida hacia el frente de tierra y con unos baluartes mucho mayores, proyecto que fue desechado por demasiado costoso. En las dos trazas, no obstante, todos los baluartes de la muralla tienen un ángulo frontal canónicamente obtuso ${ }^{19}$. Queda también perfectamente señalado el reducto del castillo de San Antonio a que nos hemos referido que, como se observa en la planta, envuelve por completo los tres baluartes exteriores del fuerte - el otro queda por entero dentro de la fortificación-, con lo cual ese punto estratégico frente al mar y la entrada del río resulta adecuadamente defendido ${ }^{20}$ (Fig. 12).

18. AGS, Guerra Antigua, leg. 744, s. fol. «Relación sobre el sitio y fortificación de Alarache y memoria...». El recurso de ceñir un fuerte triangular preexistente con una nueva fortificación se llevó a cabo también por Leonardo Turriano, ingeniero de la monarquía para Portugal, en Cascais, en 1597.

19. Adviértase cómo en una muralla que forme un arco de enorme abertura, casi rectilínea, podríamos disponer los baluartes con unos ángulos tan obtusos como quisiéramos y al mismo tiempo guardar la regla de que los flancos puedan barrer perfectamente las cortinas, ya que los mismos podrían trazarse perpendicularmente a éstas.

20. AGS, Guerra Antigua, leg. 803, s. fol. Carta del gobernador Gaspar de Valdés. Larache, 14 de mayo de 1612. Valdés hace hincapié en que la nueva planta es más «recogida» que la anterior, pero que de todas formas se podrán abrazar la villa y los dos castillos, cosa inexcusable por «la mala traça y fábrica» que tienen. «Relación sobre el sitio y fortificación de Alarache y memoria...» 


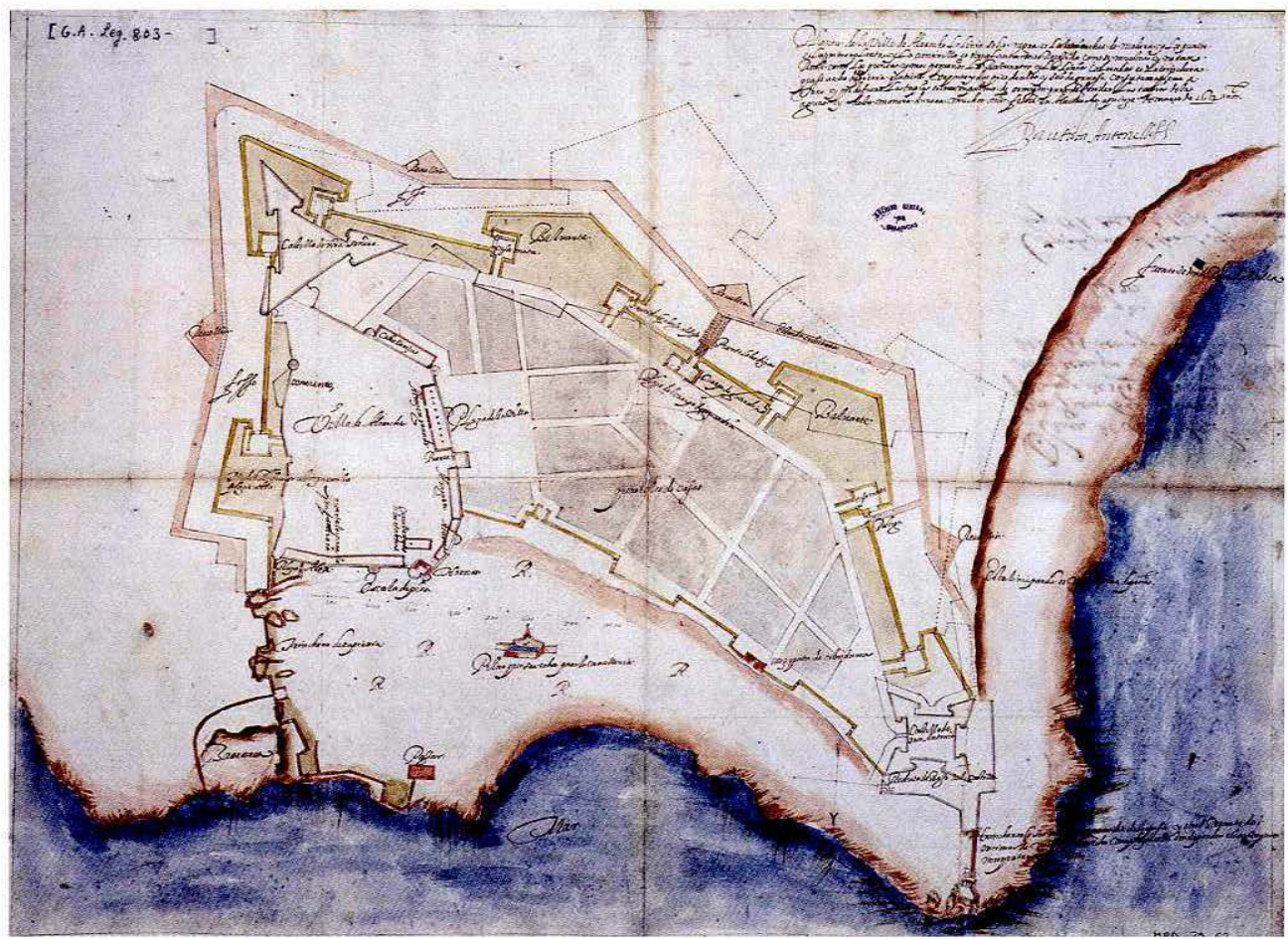

Fig. 11: Bautista Antonelli. Planta de Larache de 15 de marzo de 1612. Archivo General de Simancas, MPD, $25,62$.

De lo que allí principalmente se trataba era de trazar una línea fortificada que uniera los dos castillos, dejando a sus espaldas -lado norte- una barranca rocosa directamente frente al Lucus antes de su desembocadura en el Atlántico. Es decir, imaginémonos un gran triángulo rectángulo cuyos catetos fueran, uno la barranca en la línea de costa y el otro la margen izquierda del Lucus. Pues bien, la idea consistía en fortificar todo el recinto, pero especialmente la hipotenusa, la línea que unía los dos castillos, el frente de tierra, que era el que quedaba más desprotegido y situado de cara al interior del territorio enemigo. Esta línea, en principio muy arqueada hacia el exterior en los proyectos de Antonelli, hacia territorio magrebí, con grandes baluartes, se tendió a hacerla cada vez más «recogida», con baluartes algo más pequeños, no tan «real» ${ }^{21}$, y ocupando menos territorio. Todo en aras de

21. Cristóbal de Rojas afirma que fortificación real es la capaz de resistir artillería gruesa, que tira balas de más de 25 libras $(11,5 \mathrm{~kg})$, es decir de reyes, que tienen mucha capacidad de ataque y defensa. La no real, sólo a medida de los señores, «de menos fuerza que los reyes». Ver ROJAS, Cristó- 


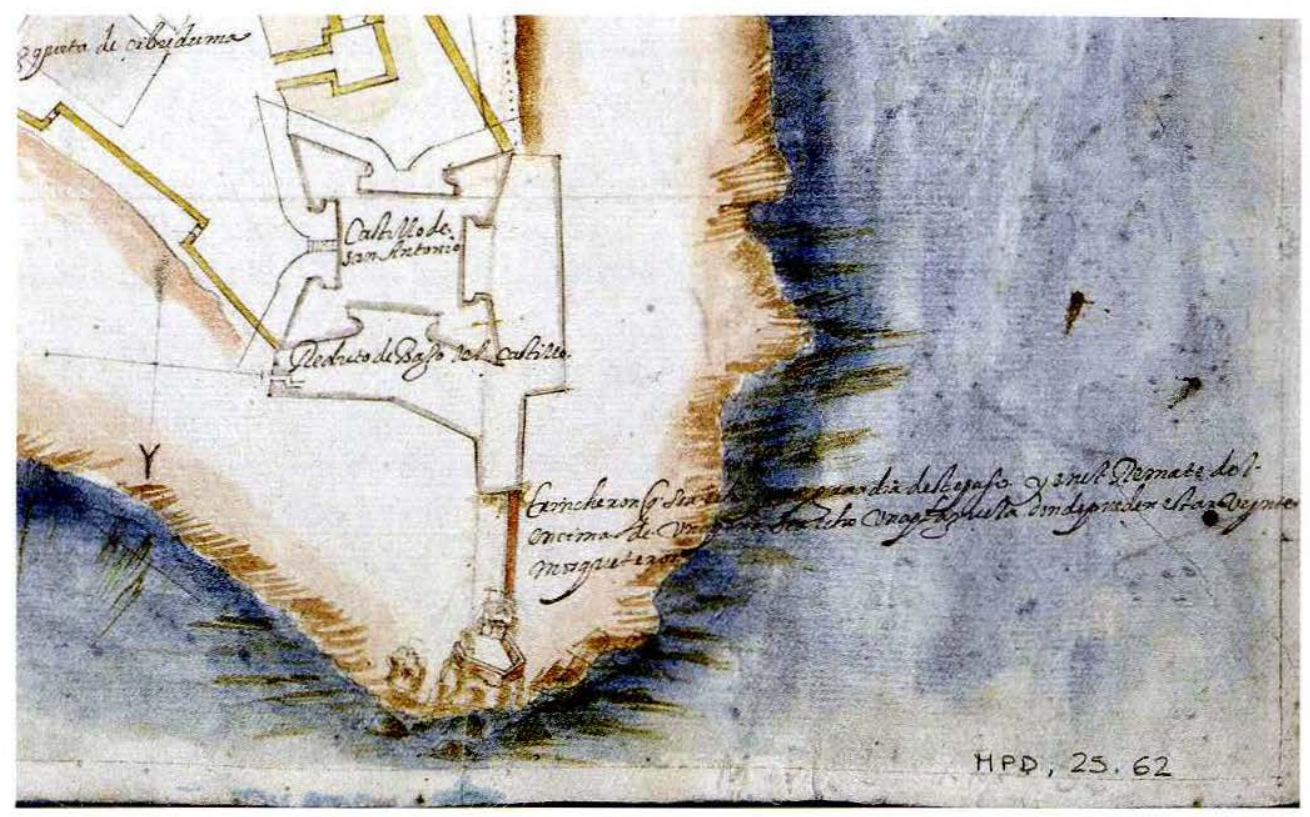

Fig. 12: Bautista Antonelli. Planta de Larache de 15 de marzo de 1612 (detalle). Archivo General de Simancas, MPD, $25,62$.

la reducción de los costes, para no sangrar en demasía los maltrechos recursos de la Real Hacienda.

Comienza un debate entre ingenieros, entre militares o entre unos y otros. Cada cual da su parecer. Ya hemos dicho que la opinión de Bautista Antonelli era la de abrazar los dos castillos con una muralla abaluartada, primero más extendida y de mayores baluartes, luego algo más recogida y de menor proporción en los traveses, dadas las exigencias que desde la corte le imponían. Todo ello queda reflejado en la planta que el ingeniero envió el 15 de marzo de 1612, ya aludida anteriormente. Meses después, Antonelli envió otra planta todavía con la muralla más pequeña, dejando fuera parte de los castillos, sin envolverlos

bal de, Sumario de la milicia antigua y moderna con la orden de hacer un exército de naciones y marchar con el y aloxarlo y sitiar una Plaça Fuerte y otros discursos militares, con una Relacion de los Reyes que ha auido desde el Rey Don Rodrigo hasta el Dignísimo Rey de España Don Phelippe Tercero; la Fortificación Real y no Real; y un tratado de Artillería y al fin un modo nuevo de fabricas dentro en la mar, las torres a menor costo y la obra más firme. 20 de enero de 1607, Ms. 9286, de la Biblioteca Nacional de Madrid, fol. 75 
por completo ${ }^{22}$. Esta última no se conserva, pero fue la solución que finalmente se adoptó como veremos en la traza de Ugarte de 1616.

El Consejo de Guerra quiso, antes de debatir la pertinente consulta, escuchar el criterio del ingeniero Jerónimo de Soto, que había sido formado al lado del gran Tiburcio Spannocchi ${ }^{23}$, ingeniero mayor del reino desde $1601,{ }^{24}$ que había muerto en 1606. Soto acompañó en sus últimos años al ingeniero italiano ejerciendo funciones de ingeniero ayudante y hombre de confianza, de lo cual fue el propio Spannocchi quien siempre se mostró dispuesto a dar fe y poner de manifiesto la gran valía de Soto como ingeniero militar ${ }^{25}$. No era extraño, por tanto, que gozase de gran prestigio y el Consejo de Guerra le encomendase misiones de supervisión y parecer, encargándole diferentes informes sobre proyectos y trazas que se consideraban de gran interés. El 14 de julio de 1612, Soto emitió su informe en el que juzgaba varias plantas de Antonelli, la de 15 de marzo de ese año, otra anterior, del año 1611, sobremarcada en la del 15 de marzo con una línea discontinua de puntos -la mayor de todas- así como una tercera recibida en la corte poco antes de la emisión del informe, datada en Larache el 8 de junio de $1612^{26}$, «la más apretada», que fue por la que optó.

Ante estas propuestas de fortificación recogida, surge la del ingeniero florentino Juan de Médicis, que trabajaba desde hacia tiempo al servicio de Es-

22. AGS, Guerra Antigua, leg. 763, s. fol. Carta de Bautista Antonelli, Larache 8 de junio de 1612. Da cuenta de una nueva traza

23. En realidad fue el ingeniero Juan de Berosain, entretenido de Spannocchi, es decir su ayudante y alumno, quien se arroga la formación de Jerónimo de Soto (que llevaba con él quince años) y de Leonardo Turriano e incluso de Cristóbal de Rojas. Véase AGS, Guerra Antigua, leg. 209, fol. 315 , citado por CÁMARA MUÑOZ, Alicia, «Juan de Herrera y la arquitectura militar», actas del Simposio Juan de Herrera y su influencia, Camargo, 14-17 de julio 1992, Fundación Juan de Herrera y Universidad de Cantabria, Santander, 1993, pág. 97.

24. Spannocchi fue el primer Ingeniero Mayor del reino que se nombró en España. Hubo que esperar al comienzo del reinado de Felipe III para que se instituyera este cargo.

25. En 1594 Tiburzio Spannocchi abogaba ante el rey para que se aumentará el sueldo a Jerónimo de Soto, del que decía en 1596 que cerca de su persona ya no tenía más que aprender en lo tocante a la profesión de ingeniero. Vid CÁMARA MUÑOZ, Alicia, Fortificación y ciudad en los reinos..., pág. 235, nota 274, citando al AGS, Guerra Antigua, leg. 437, fol. 136; y leg. 479, fols. 1-3.

26. AGS, Guerra Antigua, leg. 763, s. fol. Informe de Jerónimo de Soto sobre las plantas de Antonelli de 15 de marzo y 8 de junio de 1612, así como de otra mayor de 1611, para la fortificación de Larache. Madrid, 14 de julio de 1612. 


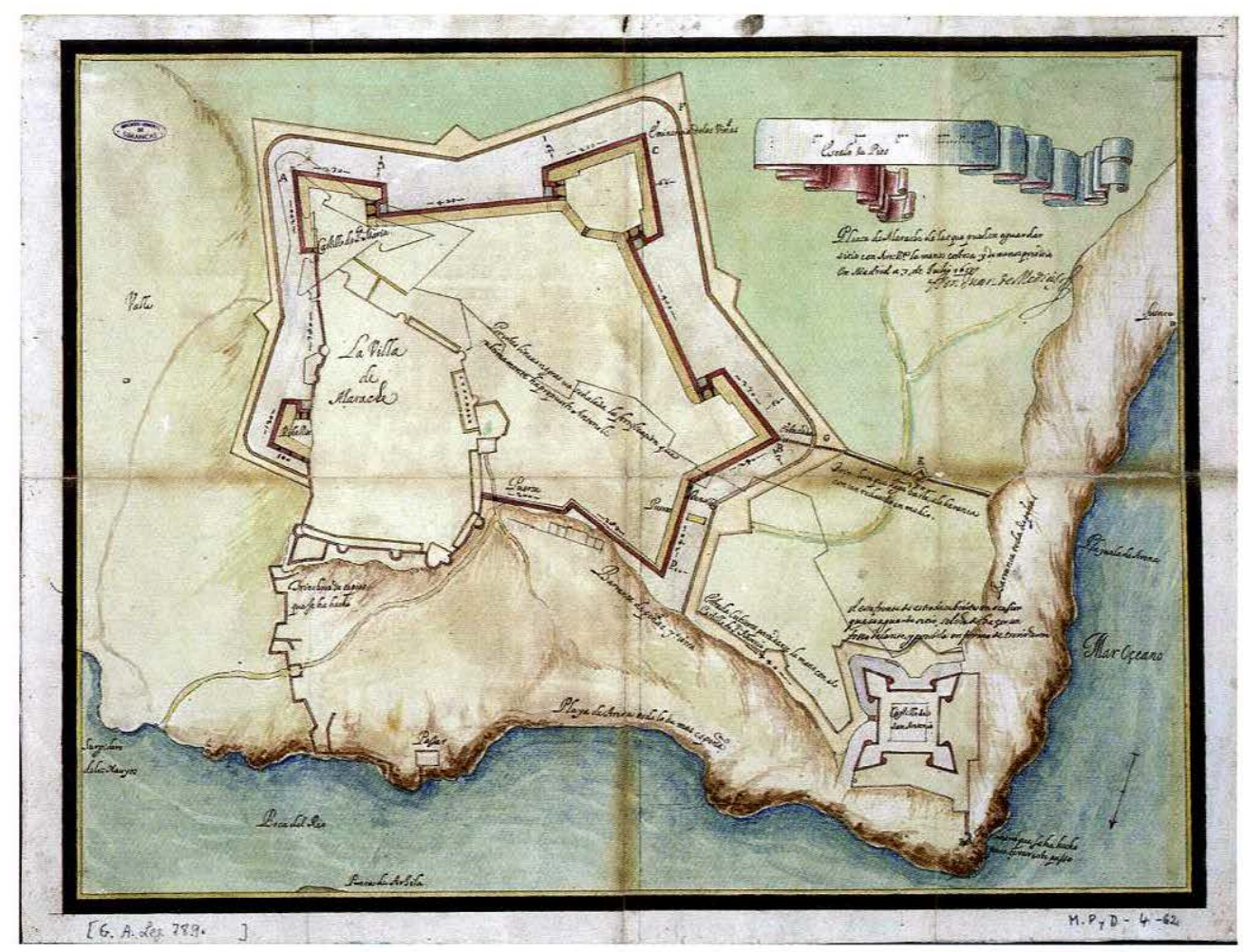

Fig. 13: Juan de Médicis. Planta de Larache de 7 de julio de 1613. Archivo General de Simancas, MPD, 4, 62.

paña ${ }^{27}$. Hijo del patricio florentino Rafael de Médicis, en 1601, con 19 años, lo encontramos en Francia esperando la recomendación de la reina María de Médi$\mathrm{cis}^{28}$. Había estado en Flandes, particularmente en el sitio de Ostende, a lo que se referirá en varias ocasiones, sobre todo cuando informa al Consejo de Guerra de su teoría sobre los parapetos de Larache ${ }^{29}$.

27. No confundir con el ingeniero y arquitecto del mismo nombre y nacido en la misma ciudad, que era hijo natural del primer Gran Duque de la Toscana, Cosme I de Médicis, del que durante algún tiempo pensamos era la misma persona.

28. Archivio di Stato di Firenze, Fondo Alessandri, filza 2, carta [folio] 1: Juan de Médicis a su tío Alamanni, que había sido embajador de Florencia en Madrid en los años finales del reinado de Felipe II, Lyon, 22 de enero de 1601 (escrita en francés).

29. AGS, Guerra Antigua, leg. 803, s. fol. «Parecer de don Juan de Médicis sobre los parapetos». Madrid, 15 de mayo de 1611. 


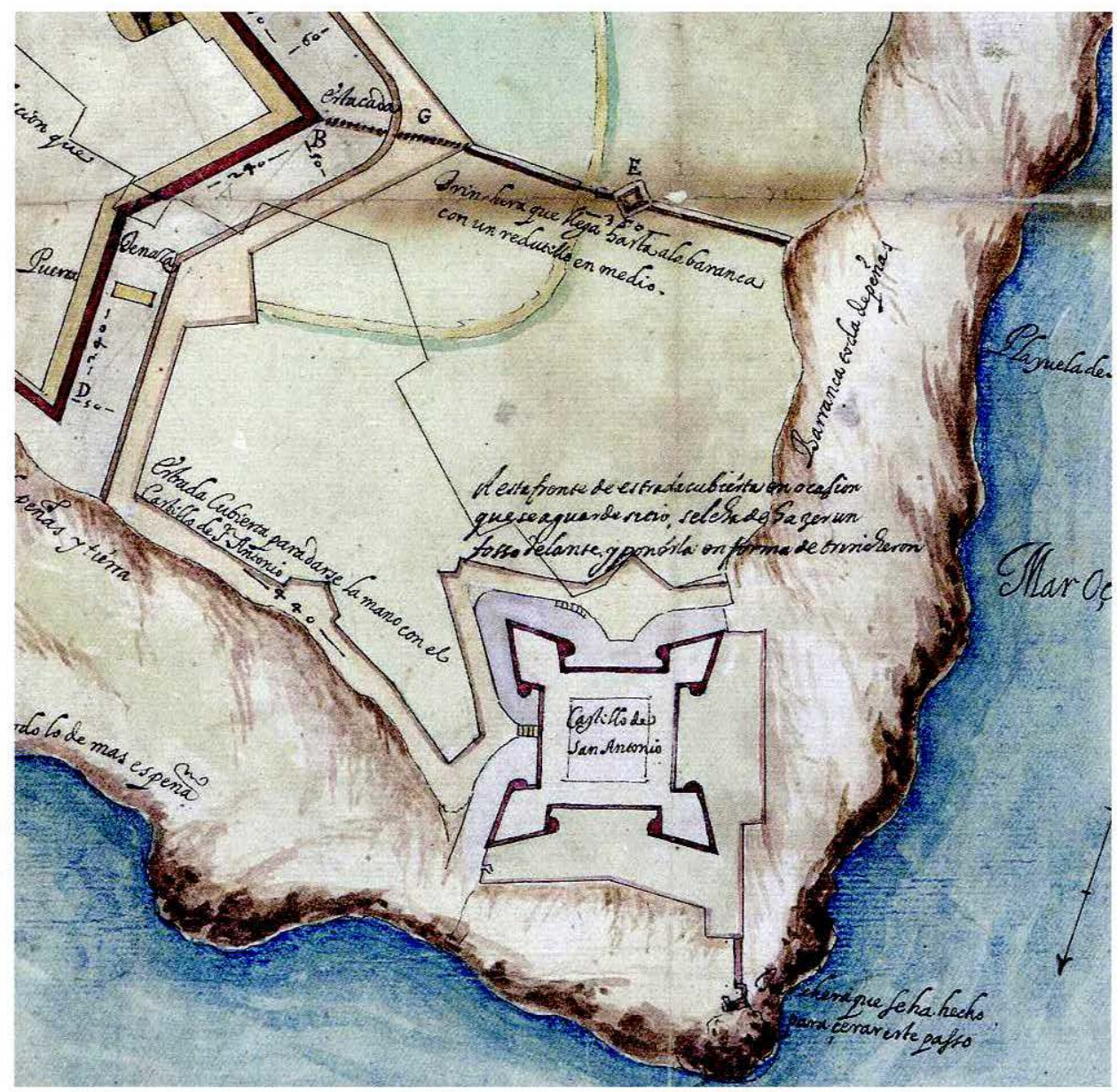

Fig. 14: Juan de Médicis. Planta de Larache de 7 de julio de 1613 (detalle). Archivo General de Simancas, MPD, 4, 62.

El proyecto de Médicis viene recogido en la traza que firma el 7 de julio de 1613 (Fig. 13). Es una concepción diferente, más cercana a una ciudadela pentagonal con grandes baluartes y tenazas «reales», es decir, con capacidad para resistir artillería gruesa, de «reyes». Dispone de un gran baluarte en el frente de la campaña cuya punta ocupa e introduce dentro de la fortificación una elevación, la «eminencia de las viñas», que las trazas de Bautista Antonelli dejan fuera, así como otro baluarte que introduce por completo en su seno el castillo de Santa María al que como todos los ingenieros considera muy débil. Al fuerte de San Antonio lo deja fuera y la parte de la fortificación que mira hacia él la resuelve con una enorme tenaza que estima será suficiente. En cuanto a la parte norte (la que mira al valle) y la del frente de la marina (que da a la desembocadura del Lu- 
cus), es de la opinión que por sus condiciones naturales era mucho más inaccesibles a los ataques enemigos, por lo que con un simple refuerzo de la muralla de tapiería medieval sería suficiente para dejarlas en defensa. Tanto la muralla de la tenaza como la del frente de tierra y la del frente del valle las ciñe con un gran foso con estrada cubierta, así como revellines ante las cortinas y el ángulo de la tijera o tenaza.

La planta será debatida junto a la última de Antonelli, la de 8 de junio de 1612, que Juan de Médicis dibuja sobre la suya, facilitando así al Consejo de Guerra una visión conjunta de los dos trazados.

Soto se inclina rotundamente - como hemos dicho- por la planta de Antonelli a la cual sólo habría que hacer pequeños añadidos que él ya había señalado.

Tras la defensa de la traza de Bautista Antonelli, Jerónimo de Soto añade otra serie de puntos señalando ahora los defectos de la de Médicis. Fundamentalmente, critica al ingeniero florentino que quisiera formar ciudadela donde no hace falta, con el consiguiente incremento en el coste. El no hacer casamatas a los baluartes, que además son vacíos y tienen una espalda de sólo treinta y cinco pies. Tampoco los terraplenos tienen la anchura suficiente, sólo treinta pies (menos de $(8,5 \mathrm{~m})$, y la muralla desde los cimientos al cordón no alcanza el grosor de ocho pies (2,23 m). Los parapetos son muy delgados, no a prueba de cañón como quiere la experiencia. La trinchera que va desde la punta B de la tenaza hasta la barranca de las peñas es «tan flaca que a dos cañonaços la des[h]arán» y además tiene en su centro un revellín (E) cuya disposición en diagonal no permite «limpiar» correctamente los lados de dicha trinchera (Fig. 14).

La traza finalmente elegida fue la de Antonelli de 8 de junio de 1612, con añadidos de Soto. Paradójicamente, la reacción de Antonelli fue furibunda cuando conoció la decisión. Dijo que había propuesto la misma sólo para que se hiciera de tapiería la trinchera de tablazón que se había levantado allí y que por su fragilidad obligaba a ser continuamente reparada, y no para «fortificaçión de sustançia». Que por eso no le había sacado orejones a los baluartes ni puesto casamatas, y que toda la línea de la fortificación del frente de tierra va «casi sobre una linia recta, cosa muy reprouada». Añadía otras razones con las que desautorizaba los añadidos de Jerónimo de Soto -reprueba la contraescarpa interior de los terraplenos y el exceso de grosor de la muralla-, sin dejar de advertir que no había podido abrir los fosos y cimientos «por la mucha edad y poca salud que tengo» ${ }^{30}$.

30. AGS, Guerra Antigua, leg.799, Carta de Bautista Antonelli al rey. Larache, 12 de abril de 1615 . 
Mientras tanto, el maestre de campo de la fuerza Gaspar de Valdés era acusado de malversación de fondos, sometido a proceso y relevado de su puesto de gobernador de Larache. Su sustituto, Pedro Rodríguez de Santisteban, brillante soldado con una extensa hoja de servicios llegó a Larache a finales de $1614^{31}$.

Con él como gobernador de la plaza, la fortificación adquirió su forma definitiva, y supo poner de acuerdo sobre el terreno al viejo ingeniero Antonelli y al joven Médicis que procedente de La Mamora camino de España hizo escala en Larache el 28 de abril de 1615. En efecto, Santisteban retuvo a don Juan en Larache los días suficientes para que pudiera estudiar sobre el terreno, junto a Bautista Antonelli y él mismo, la viabilidad de la traza que se había ordenado ejecutar desde Madrid ${ }^{32}$. Juntos llegaron a la conclusión de que había necesidad de otra planta que se ajustara más a las condiciones del terreno, cosa que hicieron, firmando la nueva traza los dos ingenieros ${ }^{33}$.

Santisteban había logrado evitar otro de los inconvenientes que todos veían a la defensa del castillo de Santa María. Este defecto consistía en una elevación rocosa que había frente a él, casi a su misma altura y que escondía el valle donde podría acampar un ejército enemigo sin ser visto desde el castillo. El gobernador probó a cortar algunas peñas de la colina para sacar piedra para la fábrica de la fortificación y se encontró con que era una cantera tan buena que además de proporcionar piedra para toda la obra, eliminaría con su extracción la elevación, el «padrastro» y descubriría el valle al castillo de Santa María ${ }^{34}$.

Sin embargo, tampoco el plan conjunto de Antonelli y Médicis pudo ser llevado a cabo. La trinchera de tablas y tierra que se había hecho con anterioridad, que seguía el plan de antonelli de 8 de junio de 1612 y que unía los dos castillos, había de de estar reparándose continuamente. Las tablas se pudrían pronto y su sustitución

31. AGS, Guerra Antigua, leg. 789, s. fol. Consulta del Consejo de Guerra proponiendo personal para el puesto de gobernador de Larache, con la respuesta de Felipe III nombrando a Pedro Rodríguez de Santisteban. El memorial de sus méritos es amplísimo, con 42 años de servicios por entonces.

32. AGS, Guerra Antigua, leg. 977, s. fol. Carta del maestre de campo Pedro Rodríguez de Santisteban, Larache, 5 de mayo de 1615.

33. AGS, Guerra Antigua, leg. 977, s. fol. Carta del maestre de campo Pedro Rodríguez de Santisteban, con la inclusión de la planta que habían acordado los ingenieros Bautista Antonelli y Juan de Médicis. Larache, 5 de mayo de 1615.

34. AGS, Guerra Antigua, leg. 807, s. fol. Carta del maestre de campo Pedro Rodríguez de Santisteban, Larache, 30 de abril de 1615. 
continua acarreaba unos gastos ingentes ${ }^{35}$. Por esta razón, el maestre de campo toma la decisión de irla sustituyendo por una muralla de hormigón, a la que añadiría los parapetos y los terraplenos, así como casamatas y orejones en los baluartes. La planta, que fue enviada a la corte con carta de Santisteban en agosto de 1616 tiene una gran importancia, pues es la que definitivamente se llevó a cabo (Fig. 15). Viene firmada por Francisco Ugarte de Acosta el 16 de julio de $1616^{36}$. No tenemos noticias del autor de la planta. Siguió, sin duda, todas las indicaciones del maestre de campo y es posible que fuera un dibujante a su cargo, como ocurría por esas fechas unos km más al sur con Luis de Miquiñón, criado flamenco de Cristóbal Lechuga, que dibujaba los proyectos de éste para La Mamora.

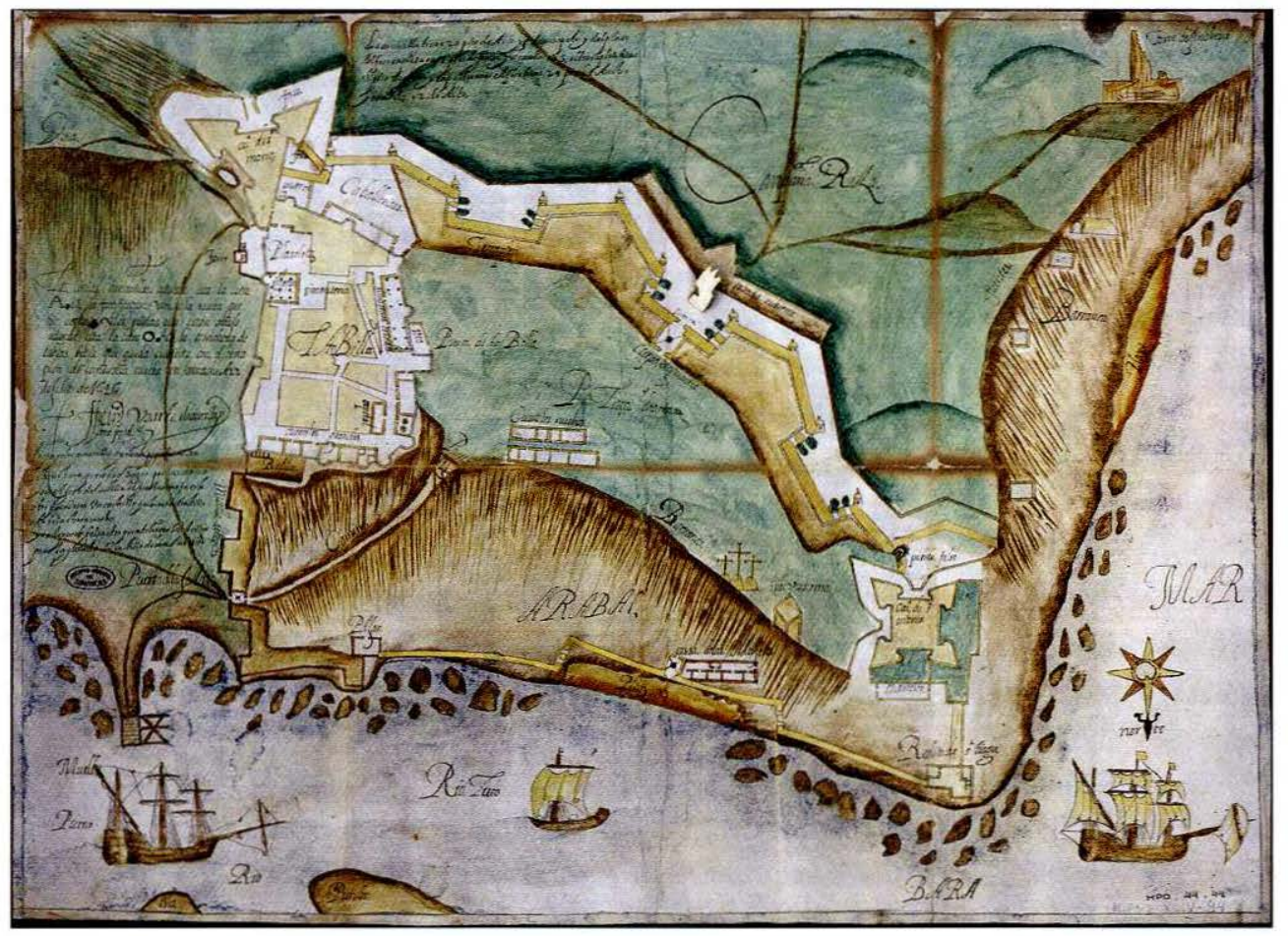

Fig. 15: Francisco Ugarte de Acosta. Planta de Larache de 16 de julio de 1616. Archivo General de Simancas, MPD, $44,44$.

1615 .

35. AGS, Guerra Antigua, leg. 813, s. fol. Carta de Santisteban, Larache 14 de agosto de

36. No Voarte como han transcrito por error algunos. Basta comparar las ges de algunas palabras en el plano, por ejemplo, «grandes» (cuarteles grandes; almasenes grandes), «guardia» (cuerpo de guardia) o «tiago» (reduto de $s^{t}$ tiago) con la de «Ugarte» de la firma para constatarlo. 


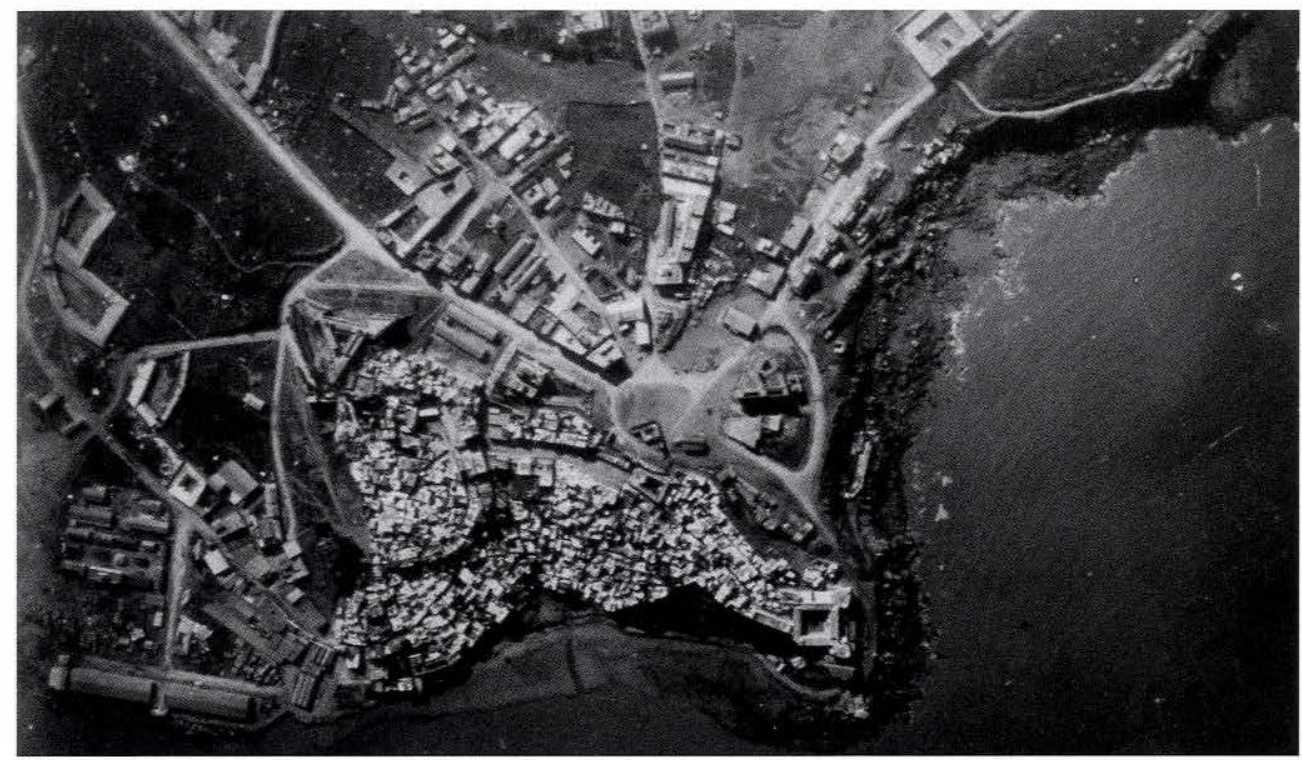

Fig. 16: Vista aérea de Larache de 1924 donde se aprecian la impronta de los baluartes y el revellín frente a la puerta principal del frente de tierra. Fotografía del fondo archivístico de la Biblioteca Nacional de Madrid.

La traza de Ugarte representa tres baluartes y uno medio que constituyen el frente de tierra de unión de los dos castillos. Los centrales albergan la puerta principal de la fortificación con su cuerpo de guardia y un puente levadizo; más allá del foso que circunda toda esta muralla principal y los castillos, una estrada cubierta atenazada y un revellín defienden la cortina de la puerta principal y los frentes contiguos de los baluartes que la enmarcan. El castillo de Santa María ha visto mejor defendido su baluarte sur al haberlo unido al de la muralla con lo que Rodríguez de Santisteban llama un cuchillo, es decir, un través que refuerza más la espalda de este agudo baluarte. Igual se ha hecho con el castillo de San Antonio, cuyo lado sur - el del frente de tierra- estaba siendo reforzado con un revellín ${ }^{37}$. Asimismo se ha consolidado la trinchera de la

37. AGS, Guerra Antigua, leg. 816, s. fol. Carta al rey de Rodríguez de Santisteban. Larache, 21 de julio de 1616. «[...] y a esta ora están acauadas [las murallas] de castillo a castillo hasta el cordón, y se ba haçiendo el parapeto y terraplenando, y tras de ello se rebocarán y se ensanchará y limpiará el foso. Y acabado con esto señiré de muralla un rebellín que tiene delante el castillo de San Antón y lo terraplenaré porque como es flaco con ello se le escusa la batería, y acauado esto se hará un cuchillo que corra por el foso del castillo de Santa María a la trinchera nueva. Conque por ambos lados quedan yncorporados los castillos con la fábrica nueba». 


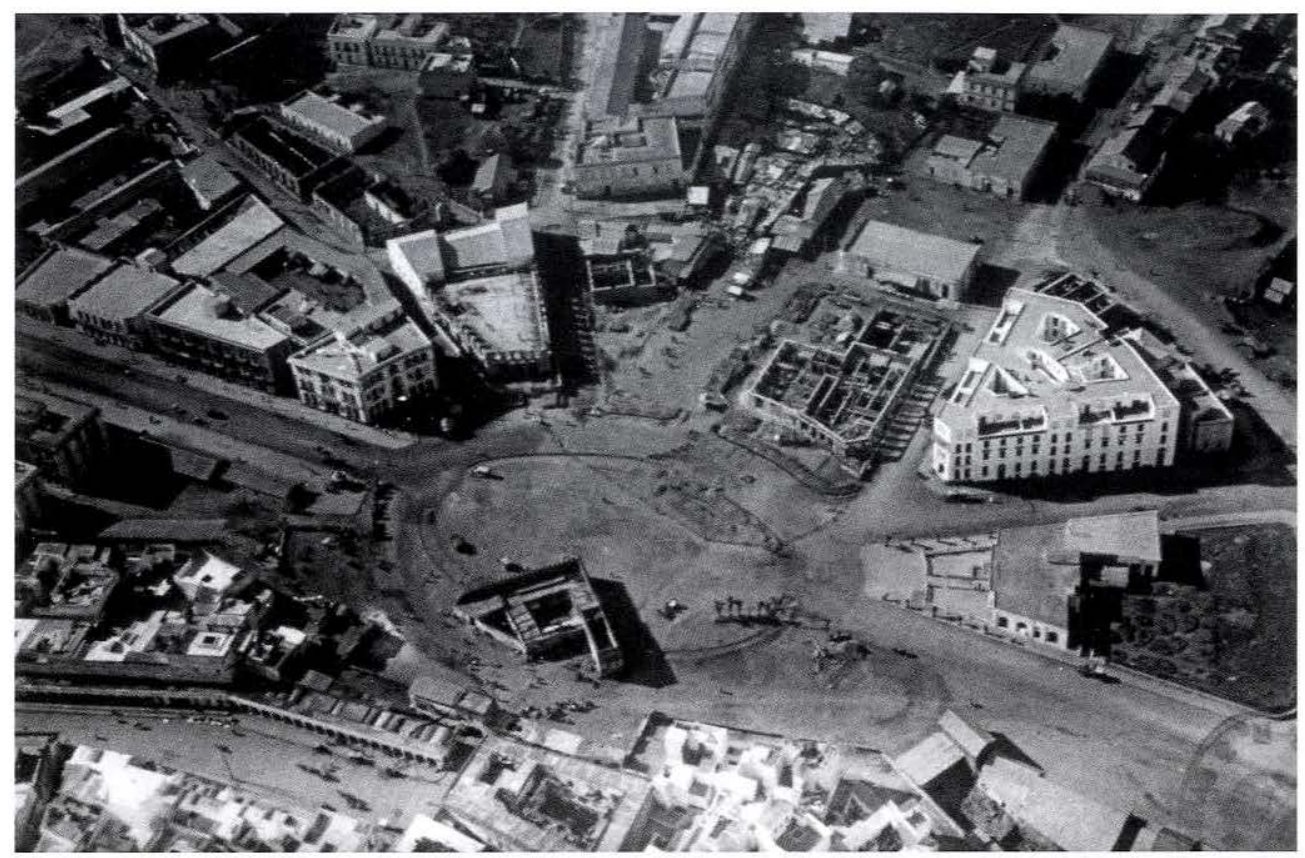

Fig. 17: Otra toma aérea de Larache de la misma fecha. Podemos apreciar el gran revellín situado frente a la puerta principal así como la impronta de la cortina y de los dos grandes baluartes que la jalonan.

marina - que mira a la desembocadura del Lucus y a la playa-desde un pajar que está junto al puerto hasta el reducto de Santiago en la misma bocana del río. Esta trinchera la representa Ugarte a base de pegar tiras de papel amarillo sobre la traza. La villa antigua de Larache queda perfectamente dibujada, rodeada de sus murallas medievales y con la iglesia, el cementerio, el hospital, los cuarteles y las caballerizas. El resto de la fortificación lo constituye la plaza de armas y los cuarteles nuevos y el arrabal donde esta el pajar y -junto a la puerta de la marina- el prostibulo, para el cual Santisteban había pedido en varias ocasiones mujeres públicas a fin de que los soldados no cayeran en la homosexualidad, muy mal vista en la época («pecado nefando») y que era castigada con la horca. Un poco al norte del castillo de Santa María, adosada a la cerca medieval, la torre cuadrangular del siglo XIV llamada del Judío, que aún pervive en la actualidad. En la zona occidental, la barranca junto al mar con varias fuentes y más al sur - parte superior derecha del mapa- la torre llamada de los Genoveses, también preexistente a la llegada de los españoles.

En las fotos áreas de la ciudad de Larache de principios de los años veinte se observa perfectamente el trazado del frente de tierra con la impronta de los ba- 


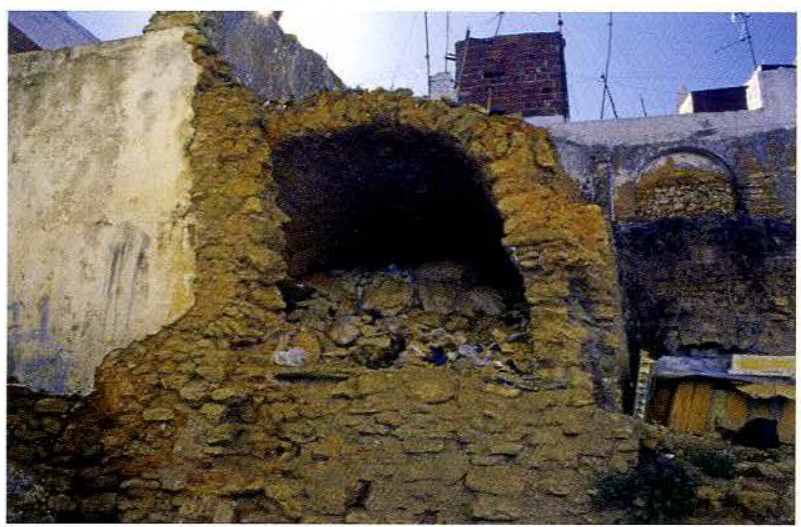

Fig. 18: Restos de la muralla del frente de tierra invadidas por las casas de la ciudad. Fotografía del autor.

luartes que correspondían a la traza de Santisteban-Ugarte (fig. 16). Asimismo podemos contemplar el gran revellín frente a la puerta principal en el momento de ser desmontado para dejar espacio a lo que sería la futura Plaza de España (Fig. 17). También si recorremos la que fuera plaza de armas de la fortificación -más tarde la villa nueva-, la trama urbana revela por donde discurría la muralla, tanto como algunos trozos arruinados de la misma, fabricados a base de mampostería como quería el ingeniero Jerónimo de Soto (Fig. 18).

Sería muy interesante la colaboración de Marruecos y España para tratar de la restauración de los castillos y algunos lienzos de la muralla, cosa que daría un valiosísimo añadido cultural y supondría una revitalización histórica de la ciudad.

\section{LA MAMORA}

Este enclave, el puerto de San Felipe de La Mamora, también llamado a veces San Miguel de Ultramar ${ }^{38}$-aunque lo más frecuente era llamarlo La Mamora, sin más aditamento- es de una importancia fundamental, junto a Larache de la que dista unas quince leguas al sur, para el estudio de las fortificaciones en tiempos de Felipe III.

En La Mamora todo es de nueva traza, el gran castillo pentagonal de San Felipe, núcleo fundamental de la fortificación y último proyecto de Cristóbal de Rojas, las torres exteriores, las murallas, los almacenes, las casas para la tropa, la iglesia, el hospital, los aljibes en fin, serán de nueva construcción. Incluso un pequeño fuerte

38. Parece ser que hasta 1643 no se había utilizado nunca el nombre de San Miguel de Ultramar y es a partir de entonces cuando se cambia el patronazgo de San Felipe por el de San Miguel. Véase PORRES ALONSO, Bonifacio, Jesús Nazareno rescatado en su tercer centenario (1682-1982), Córdoba, 1982, pág. 8 . 
preexistente a la conquista española, situado en la margen derecha del Sebú, hubo de ser rehecho por completo algo más alejado de la orilla, pues las continuas crecidas del río acabaron por llevárselo ${ }^{39}$. Por tanto estamos ante un contexto constructivo que nos permitirá observar, siempre junto a la próxima Larache, hasta dónde llegan los conocimientos de los ingenieros, la puesta en práctica de sus teorías y los debates y polémicas que se originan entre ellos; cuál es la forma predominante de construir los baluartes, las tenazas, los fosos y demás elementos de la fortificación a principios del siglo XVII; cuáles son las tendencias y cómo cursan las tensiones en el seno del Consejo de Guerra, las alianzas de determinados consejeros con este o aquel ingeniero, los largos memoriales que estos últimos envían al Consejo de Guerra, las replicas y contrarréplicas entre ellos con empleo de un abundante aparato dialéctico.

Queda claro, entonces, que el proceso de fortificación es más complejo de lo que en principio cabe esperar de la evolución tectónica de una arquitectura militar que intrínsecamente conlleva una formalidad muy lineal, muy funcional, desnuda de ornato; que las decisiones no se toman a la ligera, sino después de muchas largas controversias, muchos análisis sopesando los pros y los contras de, por ejemplo, esta forma más aguda de baluarte o aquella anchura de terraplén. Todo esto sin dejar de evaluar un factor fundamental en el abanico de las posibles soluciones: el coste de la construcción. Las arcas de la Real Hacienda están exangües desde el reinado anterior y ahora el duque de Lerma dilapida en su propio beneficio y en el de sus allegados. Para los ingenieros, por el contrario, los recursos siempre serán escasos y pasarán su vida -aquí no hay excepciónclamando por unos fondos necesarios para terminar este baluarte o el reparo de aquel lienzo de muralla.

La Mamora era una pequeña ciudad situada cerca de la desembocadura del río Sebú, a una media legua hacia el interior, que fue destruida, según nos cuenta León el Africano, en la guerra que hizo el rey Sahid de Fez a fines del siglo XIII y de la que apenas quedaban en el siglo XVI -cuando él viajaba- unas pocas ruinas. El autor granadino fue testigo de la derrota sufrida por el rey portugués Manuel I el Afortunado cuando trataba de elevar un castillo en la desembocadura del río, del que sólo le dio

39. Véase, CASTRIES, Henri de, Les sources inédites de l'histoire du Maroc: Dynastie saadienne (1530-1660), Archives et Bibliothèques des Pays-Bas, tomo I, París, Ernest Leroux, 1906. Se incluyen cartas de Muley Cidán a los gobernantes de las Provincias Unidas solicitando ayuda para la construcción de un fuerte en La Mamora, del que carecía, así como medios para la armada de navíos que le permitieran resistir el acoso del rey de España. 
tiempo a construir los cimientos y empezar muros y bastiones ${ }^{40}$. Tal vez sea este pequeño fuerte el que encontraron los españoles cuando conquistaron el puerto, aunque nada nos permite afirmarlo documentalmente y más seguro parece, como se ha dicho, fuera obra de Muley Cidán.

El perfil estratégico inigualable de La Mamora para la lucha contra la piratería y el corso se vio propiciado por sus condiciones naturales, con un puerto muy difícil de tomar desde el mar, magníficamente defendido -como señala Alonso de Contreras-por una barra marina que sólo con el creciente permite la entrada de galeras ${ }^{41}$, barra que para Gonzalo de Céspedes era «peligrosísima y mortal» ${ }^{42}$. De esta barra también habían hablado los pilotos gaditanos que acompañaron al duque de Fernandina en 1603 para intentar cegar la entrada al estuario del río Sebú. Manifestaron que no acertaban con la localización de la barra por haber quitado el enemigo las señales que había dejado el piloto Juan Caballero en una ocasión anterior, dificultándoles la localización del canal pequeño por el que siempre habían penetrado hacia el interior del río, canal que se juntaba tras el gran banco de arena con otro mayor que daba paso al magnífico fondeadero. En ese momento, las operaciones de cegado, dirigidas por el capitán Jerónimo Carro, resultaron infructuosas debido a la gran profundidad del cauce y a la enorme fuerza de la corriente en la desembocadura ${ }^{43}$. Tras su viaje, Carro expuso las buenas cualidades de la bahía interior para guarecer navíos y la facilidad de su fortificación. Sin embargo, Carro mantuvo la opinión de la imposibilidad de cegar el Sebú, «en tanto fondo y en tanta corriente» ${ }^{44}$. El proyecto de dicho ingeniero Jerónimo Carro para hundir navíos de 200 a 400 toneladas en las bocas del río, tarados de piedra, lo recoge también Castries que lo relaciona con el intento del marqués de Santa Cruz para cegar la desembocadura del río Martín, cerca de Tetuán, en $1566^{45}$.

La solución en el caso de La Mamora no ofrecía duda: Más que cegar la boca del Sebú, había que tomar el enclave. España había de hacerse con él; primero, como

40. LEÓN EL AFRICANO, Juan, De la descripción de África y de las cosas notables que en ella se encuentran, (Venecia, 1550), edición crítica y traducción del original italiano por Luciano Rubio, prólogo de Amin Maalouf, Madrid, Hijos de Muley-Rubio, 1999, pág. 116.

41. CONTRERAS, Alonso de, Derrotero Universal del Mediterráneo, en Biblioteca de Autores Españoles (BAE), tomo XC, Autobiografías de soldados, pág. 233.

42. CÉSPEDESY MENESES, Gonzalo de, Historia de don Felipe IIII, imp. de Cormellas, Barcelona, 1634 , fol. $65 \mathrm{v}^{\circ}$.

43. ARCHIVO GENERAL MILITAR DE SEGOVIA, sección $2^{a}$, división $8^{a}$, leg. 113, «Sucesos referidos al año 1603».

44. Ibídem.

45. CASTRIES, Henri de, Les sources..., Pays-Bas, tomo I, pág. 624 , nota al pie n. ${ }^{\circ} 5$. 
apoyo de Larache en la lucha contra la piratería; segundo, como puesto fronterizo de vanguardia frente a Rabat-Salé; por último, para expulsar de allí el gran foco corsario que albergaba y ganarles la mano a los holandeses que negociaban con Muley Cidán para que se lo cediera a ellos. De la importancia de mantener La Mamora en poder de España se hacía eco el mismo don Luis Fajardo, cuando ya en Madrid, once meses después de haberla conquistado, postrado en cama -moriría a finales de ese mismo añoaconsejaba al rey que no consintiese perder ese puerto, «que por mucho que algunos lo quieran deshazer, án de confesar que en toda África no ay otro hasta Orán, siendo el más caudaloso rrío della, y en el riñón de aquel Reyno» ${ }^{46}$.

Poseemos algunos testimonios gráficos del entorno de la desembocadura del Río de La Mamora o Sebú como son varios dibujos de navegantes de la época. Así, el plano enviado a la corte por don Juan Fajardo -hijo de don Luis, conquistador de La Mamora, a quien acompañó en la empresa- desde Lisboa el 9 de noviembre de 1610, que se conserva en Simancas ${ }^{47}$, mapa con rosa de 32 vientos, que incluye cotas de profundidad en la zona de la desembocadura, apreciándose en la margen izquierda la loma donde se construirá el castillo tras la conquista de 1614, ahora cubierta de matorral, con una elevación sobre el nivel de las aguas del río de 80 codos.

Don pedro de Toledo, marqués deVillafranca, gran militar del reinado, envía en 1611 otro plano de la desembocadura del río de La Mamora ${ }^{48}$, más detallado si cabe que el anterior, al ser su escala mayor (Fig. 19). En el centro del fondeadero, perfectamente abrigado de los vientos, tres navíos de gran porte están anclados rodeando una isleta arenosa. La montaña donde se construirá el futuro castillo se representa perfectamente detallada, con su forma de media luna abierta al río, toda cubierta de frondoso arbolado, un alcornocal si hacemos caso de los testimonios de los marinos. La barra de la bocana está perfectamente dibujada, es de forma triangular con el vértice hacia el interior del río, dividiendo el cauce en su desembocadura en dos ramales, dentro de los cuales figuran cotas de profundidad. A su amparo del oleaje, ya en aguas fluviales está surto un grupo de pequeños barcos. Al otro lado de la barra, en aguas oceánicas, en primer plano, una magnífica escuadra de navíos, en su mayoría de alto bordo, aguarda fondeada. La costa, tanto la que queda en el sur de la desembocadura -la parte de Salé en los textos-como la norte - la parte de Alarache- forman playas con vegetación, si bien mucho más frondosa la primera. En ambas márgenes, cerca del mar, aparecen representados dos «fortezuelos»

46. AGS, Guerra Antigua, leg. 805, carta de don Luis Fajardo, Madrid, 27 de julio de 1615.

47. AGS, M. P. y D., XIX-172.

48. AGS, M. P. y D., XIX-173. 


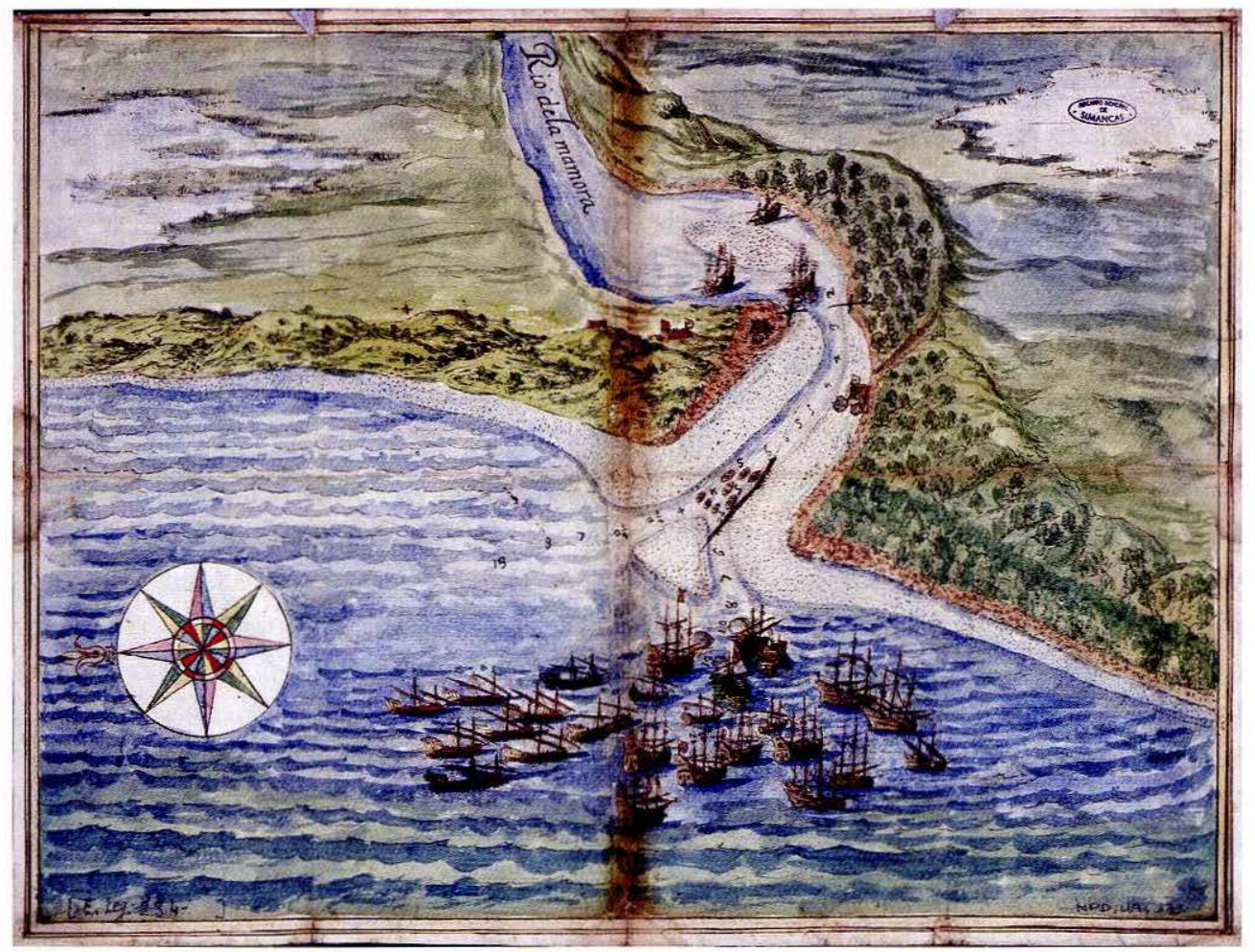

Fig. 19: Planta de La Mamora. Remitida por el marqués de Villafranca desde El Puerto de Santa María, el 4 de diciembre de 1612. Archivo General de Simancas, MPD, 19, 173.

-así los denominan las fuentes ${ }^{49}$ - de no mucha enjundia. La única inscripción del plano, junto a los números de las cotas de profundidad, es la que rotula «Río de la Mamora» sobre el cauce del mismo. En el ángulo inferior izquierdo, una rosa de ocho vientos señala al Norte mediante una estilizada flor de lis. El rico colorido aplicado al mapa, unido a la precisión del dibujo, nos ayudan a formarnos una idea bastante ajustada a la realidad de cómo sería el medio geográfico de La Mamora a comienzos del siglo XVII.

La toma de La Mamora fue decidida para mantener la orientación africana de la política exterior de la monarquía, ya con las manos libres tras la firma de la tre-

49. AGMS, secc. $2^{\text {a }}$, div. $8^{\text {a }}$, leg. 113, año 1603: «Relación del cegamiento de la barra y puerto de La Mamora hecha por el duque de Fernandina y otros sucesos de la dicha jornada». También se denominan «fortezuelos» en NOVOA, Matías de, op. cit., pág. 496. 
gua con los holandeses y deseosa de afianzar su seguridad meridional con otro puerto en la costa oeste marroquí, muy cercano a Larache (unas veinte leguas), con grandes condiciones naturales y que junto a éste fuera la guarda de las flotas de galeones que regresaban de las Indias rebosantes de plata.

En el interior de los reinos peninsulares, los moriscos habían sido expulsados en 1609, por lo que muchos de ellos -la gran mayoría- se habían radicado en el norte de África y dedicado en gran parte a una actividad, ya fuera por despecho, por venganza o por seguir los dictados del turco que les convertía en temibles predadores de sus antiguos vecinos, volcándose de lleno en el corso. Era necesario, por tanto, un nuevo enclave de apoyo a Larache, una nueva base libre de corsarios que los mantuviera a raya y reforzara la protección a las flotas de Indias.

Se puso en movimiento una magnífica escuadra a cuyo mando estaba el prestigioso militar don Luis Fajardo, general al mando de la Armada Real del Mar Océano. A ella se unieron los navíos de Flandes - llamados comúnmente de Dunkerque-, famosos por sus condiciones marineras, al frente de los cuales estaba su almirante, Diego de Santurce Horozco; las ocho galeras Reales o de España, cinco de ellas dirigidas por el duque de Fernandina -hijo del varias veces aquí citado marqués de Villafranca-, y las otras tres, las de Lisboa, por el conde de Elda. Pero como supremo capitán general de toda la armada figuraba, como se ha dicho, don Luis Fajardo, ayudado en funciones de almirante general por su hijo Juan ${ }^{50}$, el cual como ya vimos había recorrido las costas de La Mamora anteriormente y enviado a la corte un estupendo mapa de la misma (Fig. 19). Como maestre general de todo el ejército, don Jerónimo Agustín, soldado veterano de Flandes, de gran experiencia y dotado para el mando ${ }^{51}$. Pero lo más importante a efectos de la ingeniería militar fue que en la empresa tomaron parte - protagonista como veremos- dos personajes clave, situados en el más alto escalón de la ciencia militar de la época: don Cristóbal de Rojas y don Cristóbal Lechuga. Rojas, el eminente ingeniero y tratadista, culminó su carrera en La Mamora y nos dejó de ella su última traza, ya que apenas un par de meses tras la conquista hubo de regresar a España gravemente enfermo, para morir al poco de llegar a su casa de

50. El cargo de almirante general estaba inmediatamente por debajo del jefe supremo, el capitán general. Juan Fajardo era desde 1613 almirante general de la Flota del Atlántico. Vid. GOODMAN, David, El poderío naval español: Historia de la armada española en el siglo XVII, Barcelona, Península, 2001, págs. 226-227.

51. HOROZCO, Agustín de, op. cit., pág. 320. 
Cádi $^{52}$. Lechuga, tratadista en temas de artillería, fortificación y organización del ejercito, se mantuvo como maestre de campo de la plaza los siete años siguientes a su ocupación, hasta su muerte en 1621, constituyéndose en personaje central del presidio y de su fortificación durante esos primeros años críticos. Ahora, en el desembarco, estaba previsto que estuviera junto al capitán general Fajardo, bajo sus ordenes directas, y una vez hecho éste, reconociera el terreno para poder trazar las trincheras «valiéndose del capitán e ingeniero militar Christoual de Rojas, y de otros $»^{53}$. Cumplidas estas premisas, les seguirá el resto de la infantería desembarcando los pertrechos, artillería y gastadores.

Como siempre, las operaciones marítimas eran proyectadas para ser llevadas a cabo con el buen tiempo. Incluso, se tuvieron en cuenta y se estudiaron las mareas de la costa de África donde se iba a desembarcar para poder aprovecharse de la creciente de las aguas vivas y así poder fondear lo más cerca posible de la costa de La Mamora ${ }^{54}$. Consecuentemente con ello, la flota partió de Cádiz el día 1 de agosto de 1614, con un gran número de navíos de las más variadas clases y tonelajes, según nos cuenta Horozco: de alto bordo y de remos, galeones, urcas, filibotes, carabelones, carabelas, saetías, tartanas..., en total nada menos que noventa y seis navíos ${ }^{55}$, todos con el propósito de no mostrarse al enemigo en las costas marroquíes hasta no caer de improviso sobre La Mamora $^{56}$. Sin embargo, debido a un fuerte temporal, la armada hubo de refugiarse en Larache, con lo que el secreto de la operación se perdió y los marroquíes de allí dieron aviso y alertaron a los de La Mamora. Una vez pasado el temporal la escuadra continuó su trayecto y en la atardecida del día 3 de agosto quedó fondeada frente a la barra del río Sebú. Era una magnífica flota como correspondía a una nación, que a pesar de la mala administración de Lerma, todavía era poderosa ${ }^{57}$, y en estos años en que estaban vigentes los tratados de paz con los países de Europa -Francia, Vervins 1598;

52. MARIÁTEGUI, Eduardo de, El capitán Cristóbal de Rojas, Ingeniero Militar del Siglo XVI, Madrid, CEHOPU, 1985, pág. 118, citando el leg. 734, s. fol. del AGS, Guerra Antigua, Carta de aviso al rey del corregidor de Cádiz, Fernando de Añasco. Cádiz, 12 de octubre de 1614.

53. GONZÁLEZ DÁVILA, Gil, op. cit., pág. 64.

54. NOVOA, Matías de, op. cit., pág. 498.

55. En principio, dada la importancia de la armada española, en Las Provincias Unidas llegó a pensarse que el destino de la misma no era fácil que fuese La Mamora. CASTRIES, Henri de, Les sources..., Pays-Bas, tomo II, pág. 329.

56. NOVOA, Matías de, op. cit., pág. 321.

57. GOODMAN, David, op. cit., pág. 381. En el período de 1600 a 1669, es la década de 1610-1620 (sobre todo al final de la década, tras la caída de Lerma) la que experimenta con notable diferencia el mayor incremento de construcción de navíos por astilleros españoles. 
Inglaterra, 1604; Estados Generales, 1609- podía dedicar sus esfuerzos a mirar hacia el sur, a protegerse del poder turco y la piratería, tanto bereber como europea, para lo cual nada mejor que fortalecer su fronteras mediterráneas con una orla de presidios enclavados en la costa africana. De entre ellos, La Mamora debía ser uno de los más importantes y su conquista constituir un ejemplo brillante de la «reputación» de la monarquía hispana, para muchos en la corte madrileña en entredicho tras la firma de lo que sentían como deshonrosa tregua con los holandeses ${ }^{58}$

En el verano de 1614, si hacemos caso tanto de Agustín de Horozco como del propio don Luis Fajardo, unos 500 corsarios dirigidos por uno de ellos que se autotitulaba «conde de La Mamora»-con el permiso y el beneplácito del rey Cidán- habitaban el lugar ${ }^{59}$. Hacia el sur, Salé era el puerto más cercano -apenas cinco leguas- de quien podían esperar socorro, abarrotado de moriscos hornacheros, dispuestos siempre a enfrentarse a las tropas españolas deseosos de vengar su expulsión de tan solo cinco años atrás (Fig. 20). En La Mamora, escasa-

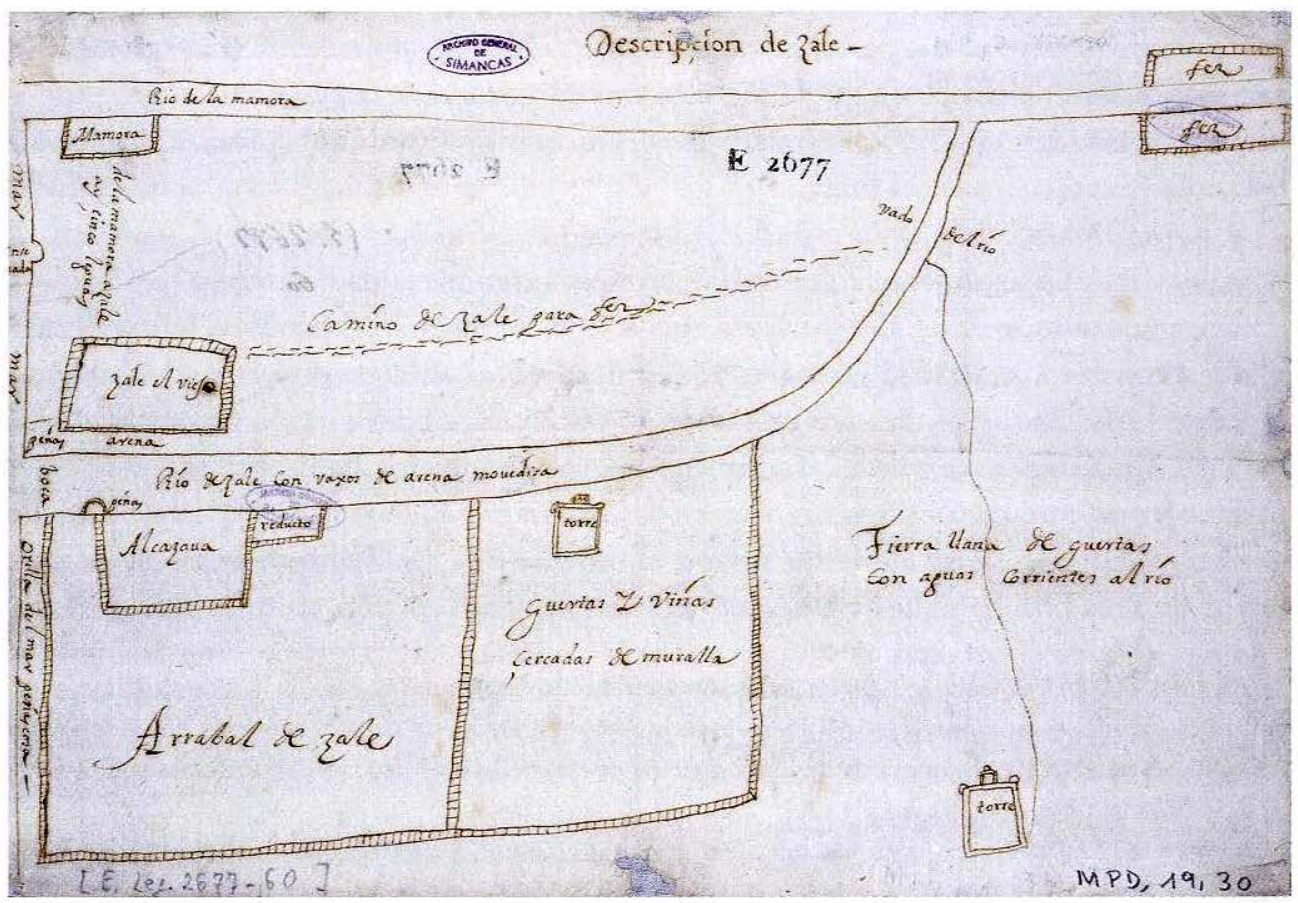

Fig. 20: Fray Julián Pastor. «Descripción de Zalé». Madrid, marzo de 1611. Archivo General de Simancas, MPD, 19, 30.

58. ElLiOTT, J. H., España y su mundo, 1500-1700, Alianza Editorial, Madrid, 1990, pág.149.

59. HOROZCO, Agustín de, op. cit., pág. 322. 
mente un fuertecillo defendía el puerto. Los corsarios hundieron una gran barcaza en la desembocadura del río, cuyos mástiles sobresalientes de la superficie habían sujetado con una gruesa cadena que atravesaba el cauce de parte a parte. Tras ella, una poderosa urca de más de trescientas toneladas, apresada a los españoles tiempo atrás cerca de Cartagena y a la que habían armado con numerosa artillería, defendía la entrada del puerto ${ }^{60}$.

Cristóbal de Rojas escribió a los pocos días de la conquista una carta a Bartolomé de Anaya Villanueva, secretario del Consejo de Guerra, en la que le da cuenta de la ocupación de las dos márgenes del río con la inclusión de la montaña de la parte de Salé, en la parte sur, elegida para erigir la fortaleza. Añadía que todo este altozano fue rodeado por una trinchera de mil cuatrocientos pasos con sus traveses y reductos y su exterior protegido con una zanja de siete pies de anchura y siete de fondo. Que se estaba trabajando en el fuerte que trazó para seiscientos hombres muy «holgados», donde cabrían mil apretados. Tendría plaza para hacer caballerizas de hasta doscientos caballos. Esta fue la traza que luego, tras la llegada de don Juan de Médicis se amplió por considerarse pequeña para los soldados que debían de alojarse ${ }^{61}$. Se llegarían a los «dos mil passos de círculo, con el fuerte en medio a modo de bonete, cuyas tres puntas miravan hazia la tierra ${ }^{62}$. No se puede describir más gráficamente la traza que Cristóbal de Rojas realizó para el fuerte.

En ella, el ingeniero lleva a la práctica con puntualidad sus ideas básicas para fortificar cuando se trate de «fundar» una nueva fortificación. Estas las había dejado expuestas con toda claridad justo tres años antes, con ocasión de dirigirle al rey -como ingeniero militar suyo- un escrito en que se oponía a la nueva moda de construir los baluartes vacíos, en vez de la tradicional y canónica de los baluartes macizos ${ }^{63}$. En primer lugar, que la fortificación que se haga sea «recogida», es decir, no demasiado

60. Ibídem, pág. 323. La urca era un tipo de embarcación pesada, de acusada manga, pero con poco calado - casco muy raso y plano- que le permitía atravesar canales y barras de poco fondo (cf. OLESA MUÑIDO, Francisco Felipe, «La marina oceánica de los Austrias», en El buque en la armada española, Madrid, Sílex, 1981, pág. 132.

61. AGS, Guerra Antigua, leg. 798, Carta de Cristóbal de Rojas al secretario Anaya de 17 de agosto de 1614 .

62. HOROZCO, Agustín de, op. cit., pág. 330.

63. ROJAS, Cristóbal de, «Vm breve discrrso del capitán Cristóbal de Rojas, Ingeniero Militar de su Magestad, sobre vna opinión nueba que á salido de que sean vazíos los baluartes de la fortificación y no maciços», Madrid, 27 de agosto de 1611, en MARIÁTEGUI, E., en El capitán Cristóbal de Rojas ingeniero militar del siglo XVI, CEDEX, Madrid, 1985, págs. 129-131. 
grande para que con poca gente pueda ser defendida mejor que una grande con mucha gente pero con mala fortificación. Siempre evitando darle al enemigo demasiados frentes ni, por supuesto, en redondo. Lo segundo, importantísimo, puesto que lo llevó a cabo aquí, en La Mamora, su última traza, es que al «fundar» esta nueva fortificación, se tengan en cuenta dos cosas: una, que «teniendo la fortificaçion las espaldas a la Mar, y que solo tenga vna frente a la campaña del enemigo, se procure que aquella frente se corte y fortifique casi en forma de media luna: porque toda ella sirua de frente, con vn baluarte en medio, y dos baluartes a los estremos de la media luna: de tal manera, que la artillería y defensa passe por delante de la frente del baluarte que está en medio de la media luna ${ }^{64}$. Esto es lo que refleja la planta de Cristóbal de Rojas para La Mamora: tres grandes baluartes apuntando hacia el interior, hacia la «campaña», el baluarte Sandoval en el centro y los baluartes San Luis y San Leonardo a los lados. La base del pentágono la sitúa mirando al Sebú, junto a la barranca, con un pequeño revellín central y dos medios baluartes en los extremos (Fig. 21).

El Consejo de Guerra le pedía a don Luis Fajardo que mandaran a Madrid un modelo en madera de la fortificación que se había trazado, para hacerse una idea más viva de cómo habría de resultar esta ${ }^{65}$. Era una práctica que se hacia con frecuencia, aunque en este caso Fajardo no pudo cumplir el encargo debido a no disponer de «entallador», por lo que «no se á sacado de madera» y se limitó a mandar la última traza de don Juan de Médicis, que había llegado a La Mamora el 18 de septiembre junto al también ingeniero Jerónimo Carro ${ }^{66}$. Estos recorrieron las obras de fortificación y estuvieron de acuerdo en todo, excepto en que les pareció algo pequeña, aunque con el añadido de la base hacia el barranco del río se había arreglado el problema. Don luis Fajardo, ironiza sobre la tendencia de los ingenieros que a esto «se inclinan siempre y pocas bezes miden la fábrica con la hazienda y oposición de los enemigos contra quien se haze» ${ }^{67}$. Pero Cristóbal de Rojas no pensaba así, como hemos visto; él valoraba también las dimensiones de la plaza así como la potencia del enemigo que debía batirla, juzgando suficiente la que trazó sin dejar de atenerse a su idea central de que fuera «recogida». Sin embargo, don Juan de Médicis aducía, tras recorrerla al día siguiente

64. Ibídem, pág. 129.

65. AGS, Guerra Antigua, s/f, leg. 789, Consulta del Consejo de Guerra de 18 de agosto de 1614.

66. AGS, Guerra Antigua, s/f, leg. 790, Carta de don Luis Fajardo, La Mamora, 14 de noviembre de 1614 .

67. AGS, Guerra Antigua, s/f, leg. 790, Carta de don Luis Fajardo, La Mamora, 24 de septiembre de 1614 . 


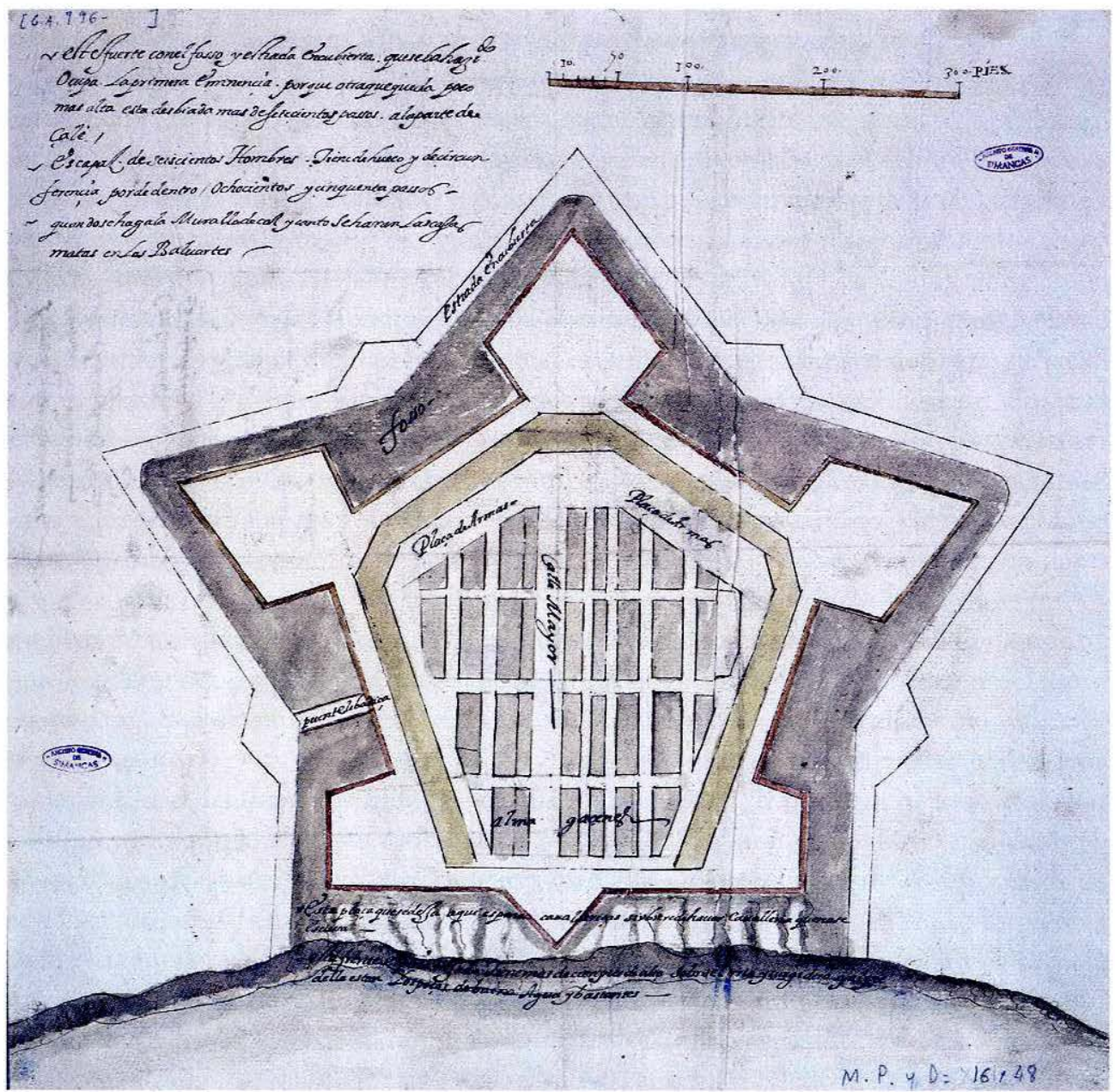

Fig. 21: Cristóbal de Rojas. «Planta de la fortificaçión que se [h]a de haçer en La Mamora». La Mamora, 13 de agosto de 1614. Archivo General de Simancas, MPD, 16, 48.

de su llegada, que «la traça del fuerte me ha paresçido algo pequeña respecto de la mucha ymportaçia del puesto» ${ }^{68}$. Cuenta Médicis que en el recorrido de reconocimiento que hizo fue acompañado por don Luis Fajardo, el gobernador Cristóbal Lechuga, el ingeniero Pedro Jerónimo Carro y el capitán Granero, sin que cite a Cristóbal de Rojas. Éste debía de estar ya muy enfermo, murió unos días después, aunque sí que

68. AGS, Guerra Antigua, s/f, leg. 797, Carta de don Juan de Médicis, La Mamora, 24 de septiembre de 1614 . 
firma -con muy débil mano- el acuerdo a que se llegó por todos los anteriores de la ampliación y nueva traza de la fortificación ${ }^{69}$.

Todos los componentes de la armada se emplearon en tareas de fortificación de la plaza. Todos, sin apenas excepción, al día siguiente del desembarco y acabada ya todo tipo de resistencia magrebí, ayudaron en la apertura de zanjas para trincheras, colocaron las estructuras de tablazón, comenzaron los terraplenes. Dice Horozco que salvo los soldados dedicados a la vigilancia, que permanecían con las armas en la mano, todos ayudaron en esos primeros trabajos de fortificación.

A don Luis Fajardo se le ordenó por decreto del Consejo de Guerra de 18 de agosto, que fuera la gente del tercio de la Armada la que permaneciera destinada de un modo fijo en la zona; por el contrario, se le indicaba que todos los soldados de la costa del Reino de Granada y los de las ciudades y señoríos que habían acudido al auxilio de la plaza - que sufría ataques marroquíes para recuperarla- debían ser devueltos a sus lugares de origen, bien que antes «se haya puesto aquello en defensa y le pareçiere que no pueden hazer alli falta» ${ }^{70}$. En la corte de Felipe III se había comprendido que el puerto de La Mamora, a pesar de los primeros ataques desesperados de los bereberes, no correría - una vez, siquiera elementalmente, fortificado- peligro verdadero de perderse. Además, Muley Cidán permanecía por entonces distraído con revueltas interiores, como la de su sobrino Abdalá -hijo de Muley Xeque, que había entregado Larache cuatro años antes- o frecuentes sublevaciones de santones morabitos, fanáticos religiosos que pretendían usurparle el trono ${ }^{71}$.

Fajardo, antes de volver a España gravemente enfermo, hubo de dejar los asuntos de fortificación de La Mamora y todo el fuerte en buenas manos. El elegido,

69. AGS, Guerra Antigua, s/f, leg. 790, «Relación q[ue] ynbia don Luis Faxardo con carta para Su M de 23 de septiembre de 1614 de lo q[ue] él y los yngenieros que se hallan en La Mamora han resuelto sobre lo del fuerte q[ue] alli se está haziendo»

70. AGS, Guerra Antigua, leg. 789, s/fol., «Decreto del Consejo de Guerra de 18 de agosto de 1614 con instrucciones para don Luis Fajardo.

71. CASTRIES, Henri de, Les sources inédites..., Archives et Bibliothèques de France, tomo II, París, E. Leroux, 1909, págs. 577 y 578, carta del representante francés en Madrid, Vaucelas, de 17 de septiembre de 1614, al consejero de su país, Mr. Puiseux, informándole de lo relativo a La Mamora. En nota al pie de la pág. 577, Castries reflexiona: «l'achèvement imminent des travaux de fortification dirigés par Lechuga [resaltado mío] allait permettre de diminuer sans danger les effectifs de la garnison». Del mismo autor, véase también, Les sources inédites..., Archives et Bibliothèques d'Espagne, tomo I, París, Ernest Leroux, 1921, carta del duque de Medina Sidonia a Juan de Cirica de 22 de septiembre de 1614. 
recomendado fervientemente por el propio don Luis, no fue otro que el capitán Cristóbal Lechuga, que tanto y tan bien se había distinguido en las operaciones de ocupación. Felipe III le nombró gobernador de la fuerza y alcalde del enclave, con título de maestre de campo, máximo responsable de la fortificación del mismo. Habían quedado bajo su mando un total de «dos mil y quinientos soldados de presidio», es decir, de guarnición en la plaza, número de soldados necesario para que, al menos mientras se construyesen las trincheras, fosos y murallas del nuevo fuerte este se mantuviera en defensa. Porque una vez «inexpugnable», con menos soldados estará bien defendido este presidio de La Mamora, «puerta y entrada tan importante para la África, su ojo, y su puerto tan principal del Estrecho afuera, en el qual assi mesmo quedaron cincuenta pieças de artillería de bronce, gruesas y de todos calivos, con sus caxas, ruedas y muniçión» ${ }^{72}$.

Las deliberaciones del Consejo de Guerra para nombrar gobernador del presidio de La Mamora culminaron el 28 de agosto con la elección de Cristóbal Lechuga para el cargo, pues como persona «parece que será a prossito la del Capitán Xpoual Lechuga, que propone don Luis, por lo bien que le asiste y ser tan antiguo Capitán y plático de las cosas del artillería y fortificaçiones y la satisfaçión que ha dado de las cossas desta professión que se le han encargado» ${ }^{73}$. El último día del año se consultó por el Consejo y aprobó Felipe III que el título que había de darse a Cristóbal Lechuga al frente de la fortificación de La Mamora sería el de «Maestro de campo de la gente de guerra de aquella plaça», con un sueldo de 200 ducados al mes, ya que al gobernador de Larache se le dan esos 200 ducados, y el puesto de La Mamora es tan importante como aquel, dice el Consejo. También se le dará el título de «Alcaide Gouernador» ${ }^{74}$. Si tenemos en cuenta lo que ganaba el capitán de una compañía, 40 ducados, o el maestre de campo de todo un Tercio, con más de dos mil soldados a su cargo, 80 ducados $^{75}$, el sueldo de los gobernadores de las plazas de Larache y La Mamora era muy importante, lo que indica la alta consideración que, sobre todo por su categoría estratégica, se tenía de ellas y de las personas que se destinaban a su gobierno. El propio Cristóbal

72. Ibídem, pág. 348. Véase también NOVOA, Matías de, op. cit., pág. 503, que coincide en el número de soldados y piezas de artillería dejadas por don Luis Fajardo a su regreso a España.

73. AGS, Guerra Antigua, leg. 789, s. fol. Consulta del Consejo de Guerra de 18 de agosto de 1614, «Deliberaciones para la elección de gobernador de La Mamora».

74. AGS, Guerra Antigua, leg. 789, s/fol., Consulta del Consejo de Guerra de 31 de diciembre de 1614, «Sobre el nombre y sueldo que se ha de dar al capitán Lechuga para el gobierno de La Mamora»

75. QUATREFAGES, René, Los Tercios españoles (1567-1577), Madrid, Fundación Universitaria Española, 1979, pág. 180. 
Lechuga cuando se dirigió al rey para agradecerle su nombramiento, pone en valor su calidad y trayectoria militar, hace una breve relación de sus muchos servicios a la corona, refiriéndose especialmente a que el conde de Fuentes le nombró, nada menos, que general de toda la artillería del Estado de Milán durante los diez años en que Fuentes fue gobernador del Milanesado ${ }^{76}$. Lechuga fue su mano derecha, encargado-aparte de su título como general de la artillería - de todas las misiones delicadas, supervisor de las fortificaciones del Estado, director de la construcción del Fuerte de Fuentes, verdadero «ingeniero de caminos» para abrir las vías del Nuevo Camino Español a Flandes a través del Tirol y Suiza, una vez que la Paz de Lyon de 1601 forzó el abandono del camino tradicional a través de Saboya y el Franco-Condado.

Por esa comunicación de Cristóbal Lechuga muy cercana ya la Navidad conocemos los avances de la fortificación, prácticamente con su forma definitiva. Adjunta una planta posiblemente dibujada por su ayudante y criado (a quien Lechuga formó) Luis de Miquiñón - la planta y alzado de la torre de san Cristóbal sí que son debidas a la mano de Miquiñón con toda seguridad como veremos más adelante- donde se señalan los nombres de los baluartes y medios baluartes, las puertas de Fez y de Salé, el camino de bajada al río, los revellines, etc. (Fig. 22). Para entonces estaba hecha toda la estrada cubierta desde la puerta de Salé hasta el revellín san Roque ${ }^{77}$, de piedra seca por falta de cal y su muralla de cuatro pies de ancho por siete de alto de tierra vestida de piedra. Dice que se puede ir recorriendo toda la estrada cubierta sin ser vistos desde el exterior. El foso entre el medio baluarte Guzmán ${ }^{78}$ y la cortina que enlaza con baluarte San Leonardo está entre quince (por donde más) y diez pies de profundidad por donde menos, habiendo de llegar por lo menos hasta los dieciocho pies. El revellín Maqueda ${ }^{79}$ está acabado de madera y terraplenado y se encuentra entra el baluarte san Leonardo y el baluarte central, llamado de Sandoval en honor, no cabe duda, de don Francisco de Sandoval y Rojas, el todopoderoso duque de Lerma, cuya firma valía tanto como la del rey. El foso se va cavando hasta el tercer baluarte, el baluarte San Luis, ${ }^{80}$ aunque

76. AGS, Guerra Antigua, leg. 794, s/fol., Carta del maestre de campo Cristóbal Lechuga al rey, San Felipe de La Mamora, 18 de diciembre de 1614.

77. San Roque, santo intercesor contra la peste, fuerte contra este mal tan extendido, era titular con frecuencia de elementos de fortificación.

78. Tal vez en honor del duque de medina sidonia, don Alonso Pérez de Guzmán, de quien dependía Larache y La Mamora.

79. En honor del $4^{\circ}$ duque de Maqueda, don Jorge de Cárdenas Manrique, que intervino con un gran contingente de tropas en el socorro de La Mamora.

80. En honor del santo de don Luis Fajardo, conquistador de La Mamora. A quien también se dedica un medio baluarte, esta vez por su apellido, y otro medio baluarte llamado de San Juan po- 


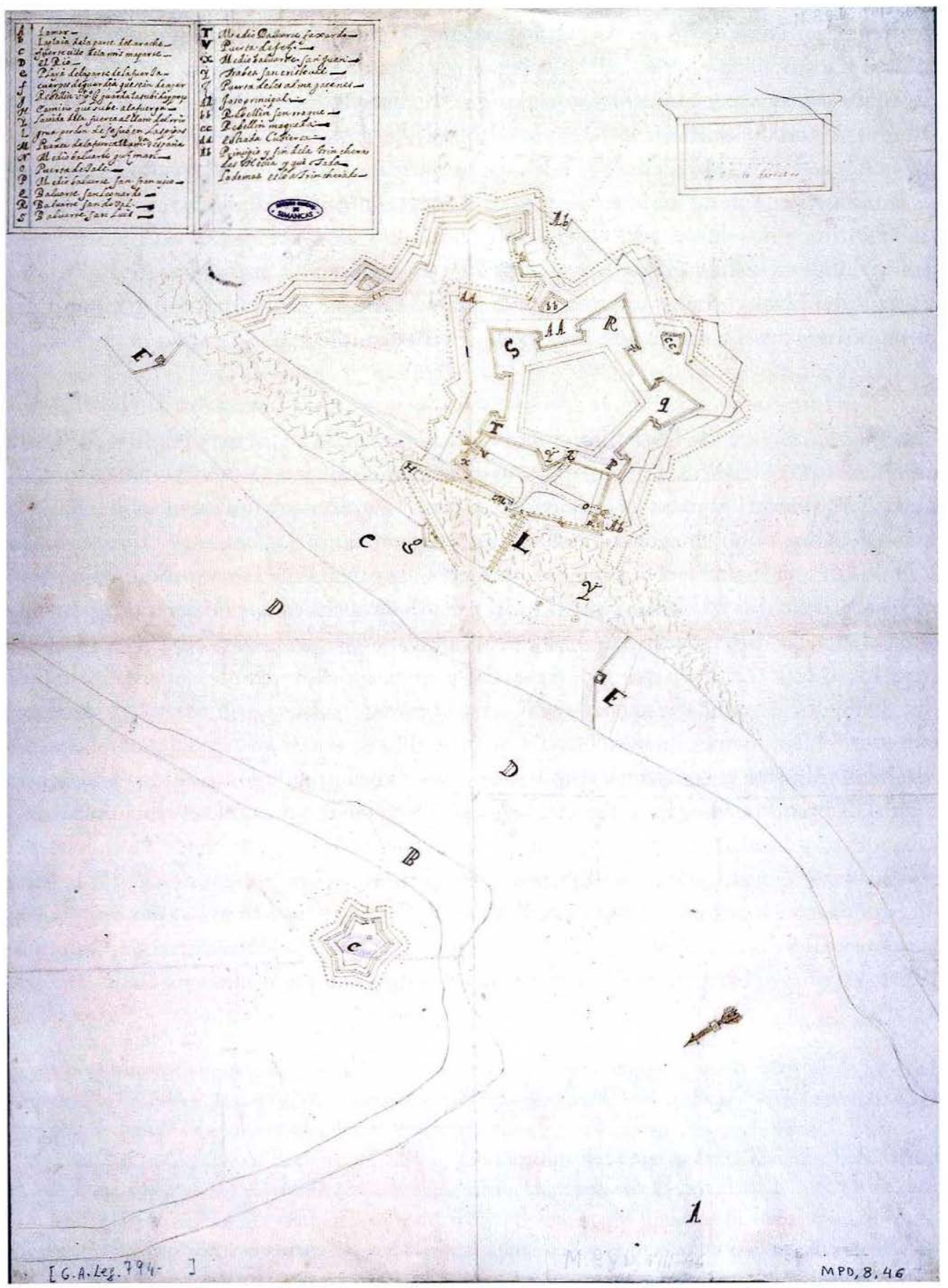

Fig. 22: «Planta del fuerte de La Mamora». Remitida por el capitán Cristóbal Lechuga a S. M. el 18 de diciembre de 1614. Archivo General de Simancas, MPD, 8, 46. 


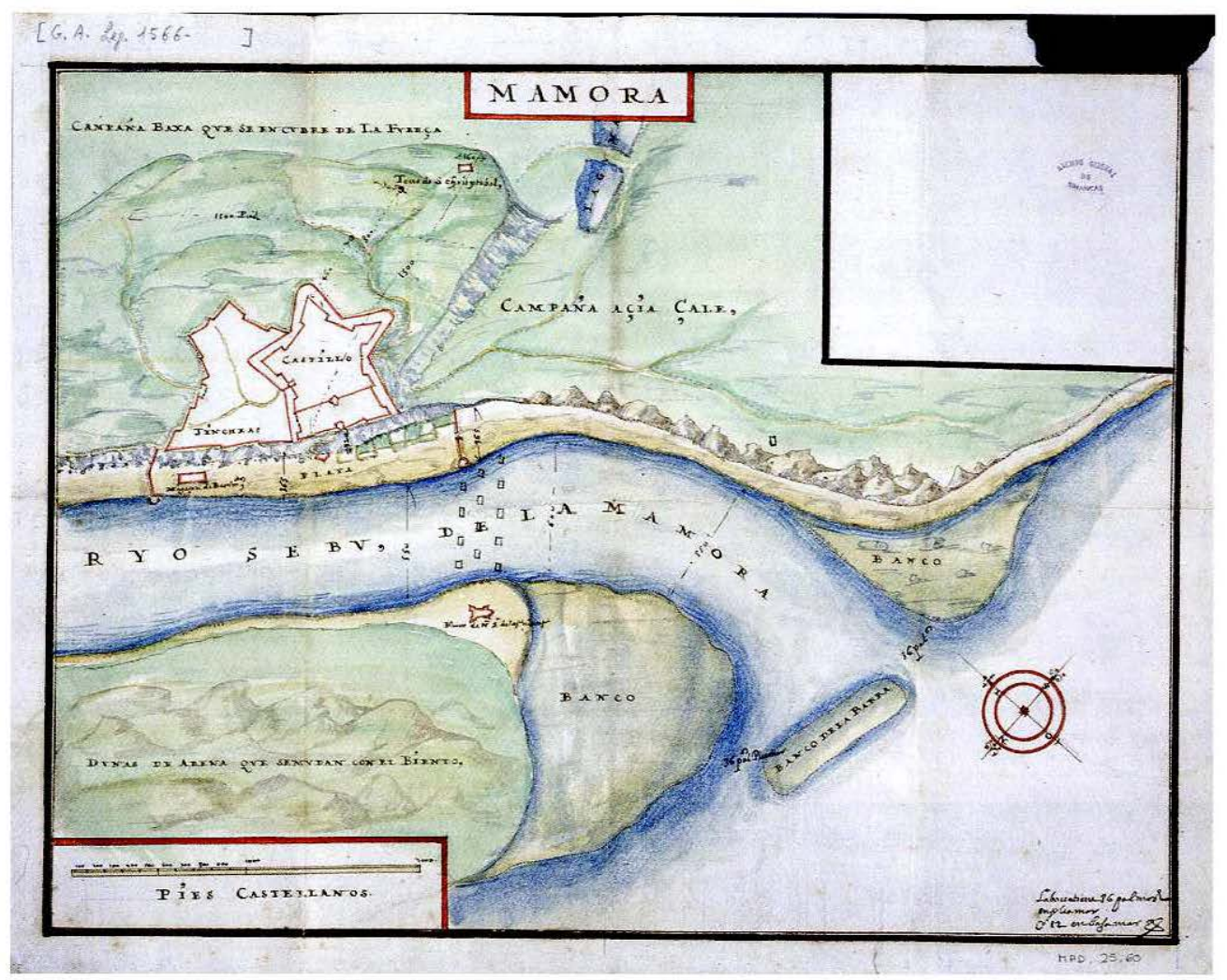

Fig. 23: Planta para reducir la fortificación de La Mamora de forma que se pueda defender con menos gente y gasto. Acompaña a un informe de Jerónimo de Soto (hijo). Madrid, 18 de enero de 1633 . Archivo General de Simancas, MPD, 25, 60 .

aquí sólo se han conseguido ocho pies. Asimismo esta hecha la muralla que mira al río, en cuyo centro se encuentra la puerta de España, que da salida al camino que baja al río y que ha sido construida de piedra seca por falta de cal. Curiosísimo es el dato que aporta Lechuga de la lentificación de los trabajos debido a haber encontrado en el terreno donde se cavaban una parte de los fosos «un mármol muy duro», material cuya existencia ha sido constatada arqueológicamente en la actualidad ${ }^{81}$.

81. Cuando en este II Congreso Internacional Patrimonio y Ciudad tuve la ocasión de comentar el dato con el Sr. Samir RAOUI, autor en el mismo de una brillante ponencia sobre La Mamora, se asombró muchísimo: él había encontrado en sus excavaciones arqueológicas en el fuerte gran cantidad de mármol de una variedad muy dura. Samir RAOUI es actualmente director del Museo Arqueológico de Rabat y autor de una tesis doctoral sobre La Mamora, aún inédita, que muy pronto esperamos ver publicada. 


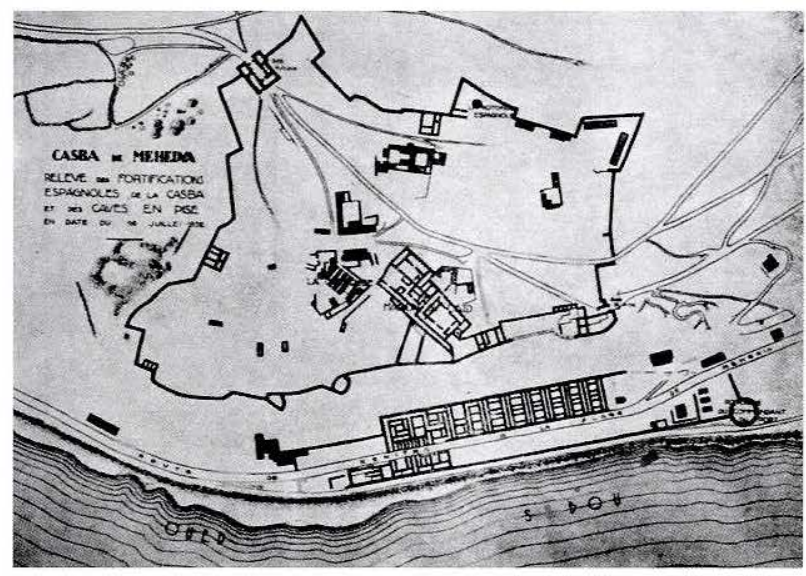

Fig. 24: Casba de Mehedya. Relève des fortifications espagnoles de la casba et des caves en pisé, en date du 16 de juillet de 1932. Tomada de GUASTAVINO GALLENT, Guillermo, La toma de La Mamora relatada por Tirso de Molina, Instituto General Franco para la investigación hispano-árabe, Larache, 1939.

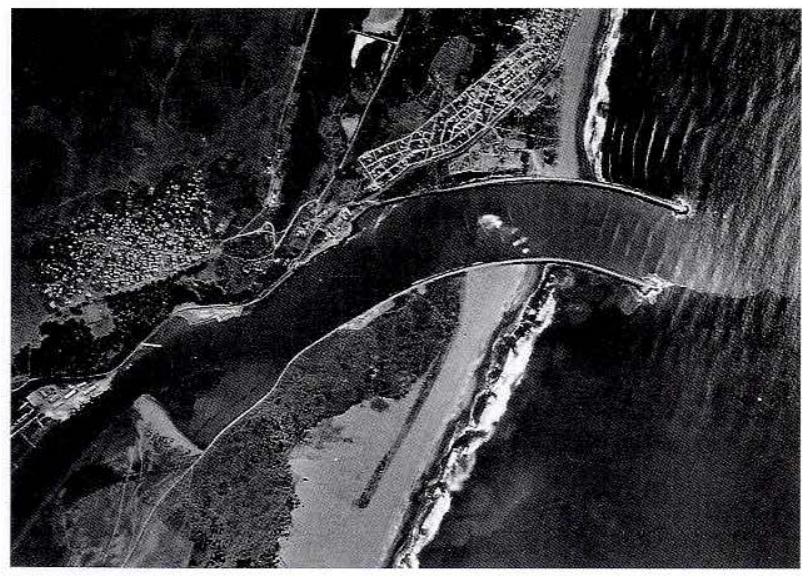

Fig. 25: Vista aérea de La Mamora. Gobierno marroquí. Cedida amablemente por D. Samir Raoui.
En suma, la fortificación, ya en esta fecha tan temprana adquirió su forma definitiva. Lo podemos comprobar si cotejamos la planta de finales de 1614, con la bellísima -por el color, la traza, la rotulación- de 1631 atribuida a Jerónimo de Soto hijo (Fig. 23). Igualmente, si avanzamos en el tiempo hasta situarnos en las primeras décadas del siglo $\mathrm{XX}$, las variaciones son muy pequeñas como atestigua el plano francés de época del Protectorado (Fig. 24); esto también podemos comprobarlo en la todavía más reciente fotografía aérea del Gobierno marroqui ${ }^{82}$, o en la vista obtenida por satélite de 2007 (Figs. 25 y 26).

Merecen también nuestra atención las torres que se construyeron en $\mathrm{La}$ Mamora. Se trata de tres torres, dos en la margen izquierda y la otra en la derecha (Fig. 27). La de San José, situada junto al río en la misma margen donde se encuentra la fortificación, pero en la playa y cerca de la desembocadura con objeto de poder guardar la barra del río y la playa. La diseñó don Juan de Médicis, aunque Cristóbal Lechuga hubo de añadirle matacanes, «fue neçesario aiudar 


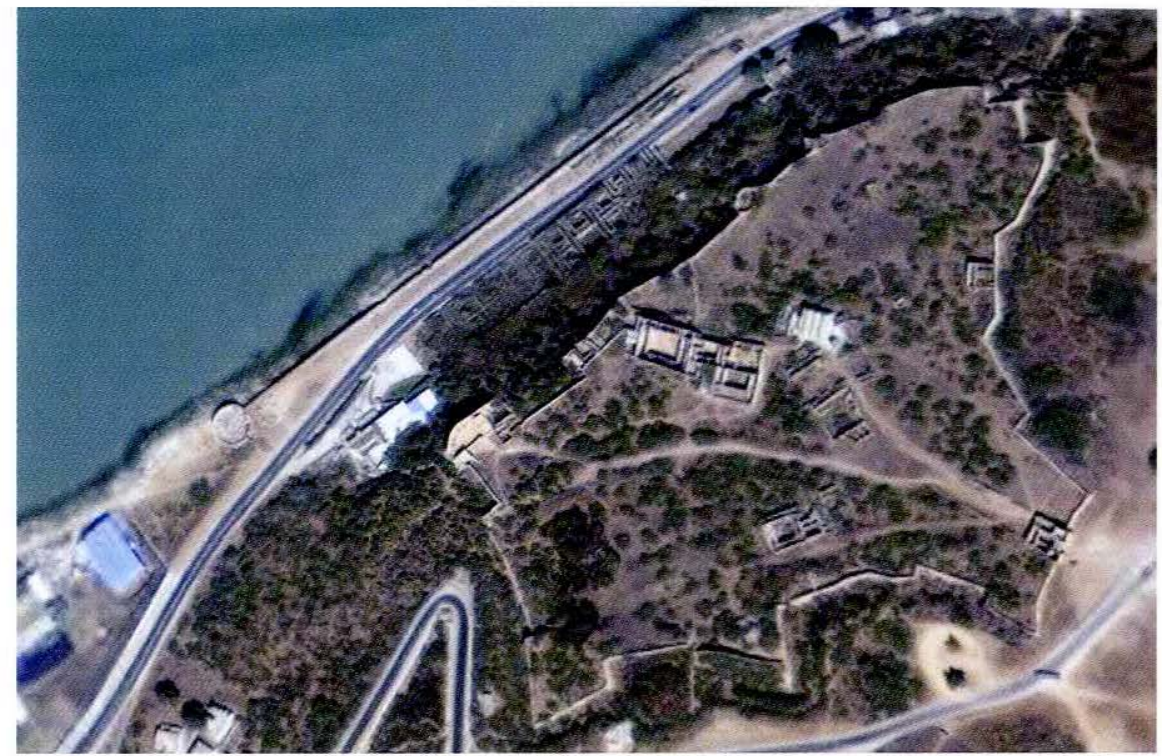

Fig. 26: Vista de la fortificación de La Mamora obtenida por satélite (Google Earth).

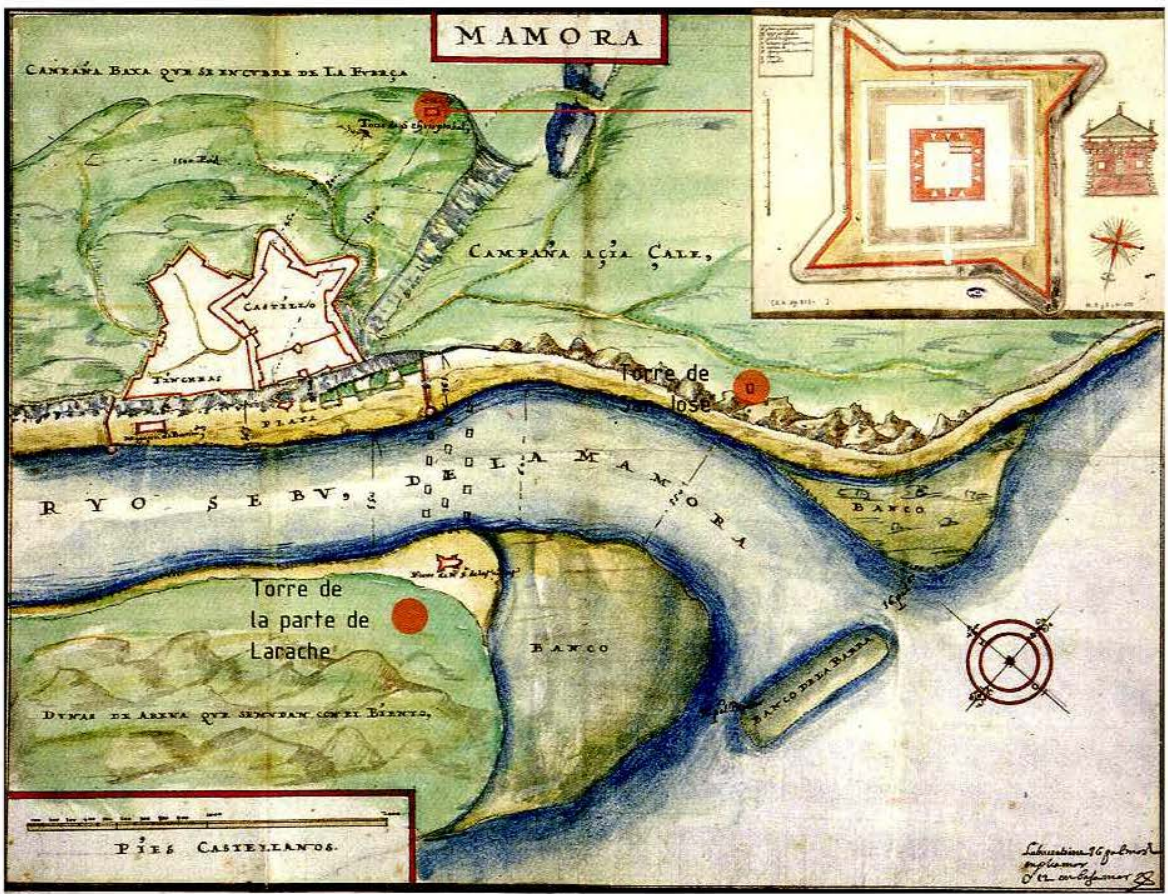

Fig. 27: Planta de La Mamora de 18 de enero de 1633 (Archivo General de Simancas, MPD, 25, 60), con el añadido virtual por parte del autor de los sitios donde se encontraban las torres de San José, la de la «Parte de Larache» y la de San Cristóbal (ya también señalada en el mapa original). 


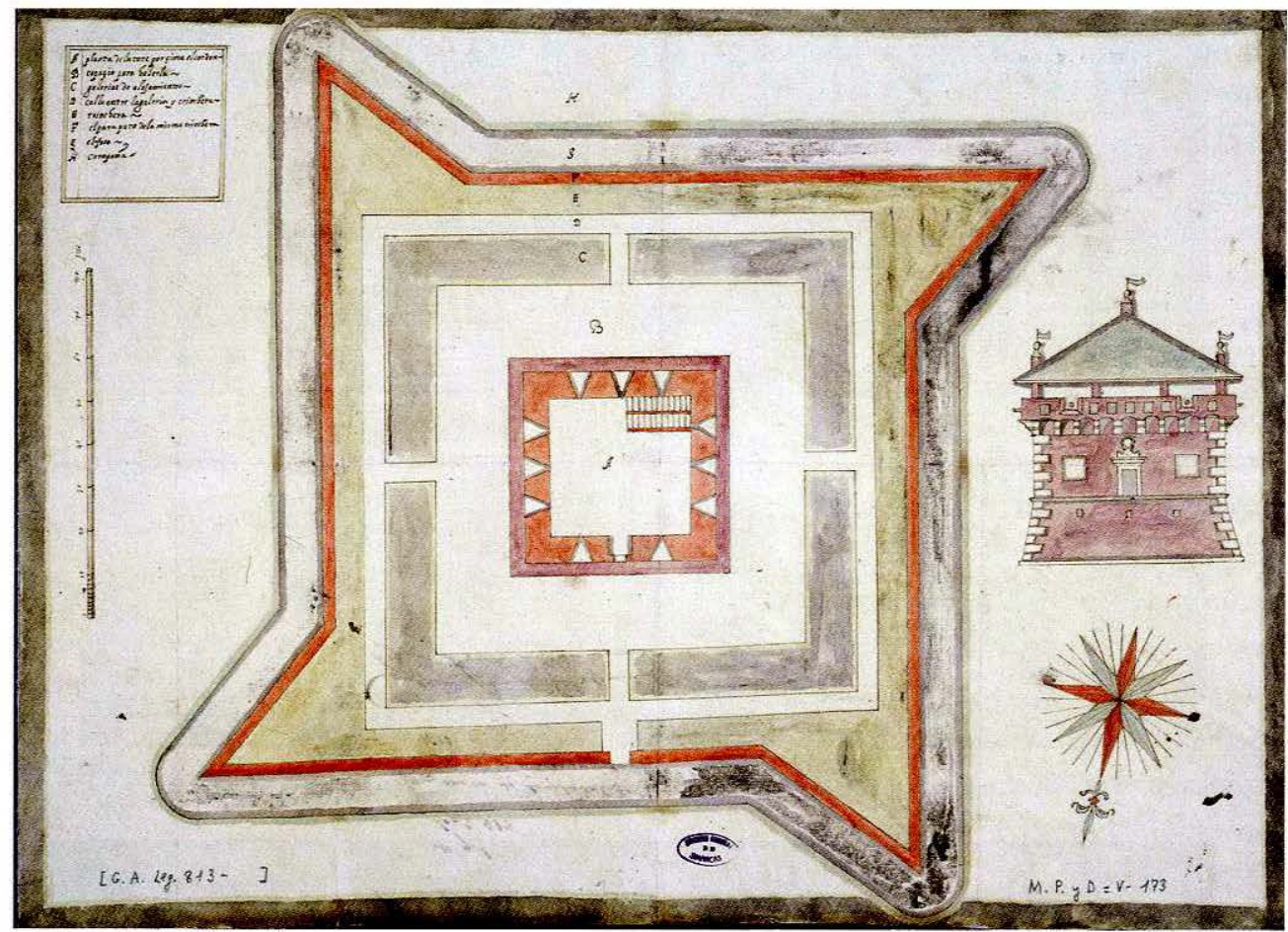

Fig. 28: Cristóbal Lechuga-Luis de Miquiñón. Planta y alzado de la torre de San Cristóbal, así como de los alojamientos y estrada cubierta que se construyeron alrededor de la misma para defenderla mientras se erigía.

con mésolas [ménsulas] $\gg^{83}$, para que las piezas de artillería tuvieran más espacio para su retroceso. Las otras dos, la de San Cristóbal - situada en los hachos- y la de la parte de Larache -en la margen derecha- aún no estaban hechas en mayo de 1616 y Lechuga decidió no ejecutar las trazas que le había dejado Médicis «para q[ue] hechas no suçeda lo mismo que en la dicha» ${ }^{84}$.

La más interesante para nosotros es la de San Cristóbal (nos gusta pensar que se la llamó así en honor del maestre de campo y gobernador de la fuerza ${ }^{85}$ ) pues conservamos la

83. AGS, Guerra Antigua, leg. 813, s. fol. Carta de Cristóbal Lechuga. La Mamora, 6 de mayo de 1616.

\section{Ibídem.}

85. Además, san Cristóbal era elegido como titular de muchos baluartes y fortificaciones por haber sido muy fuerte y corpulento - un gigante-, muy apropiado, por tanto, como nominador de ellos. 
magníficas trazas que realizó Luis de Miquiñon, criado flamenco al que Lechuga formó y del cual advierte al Consejo de Guerra en la misma carta de 6 de mayo de 1616, se le debe pagar sueldo, «porque se me quiere ir a su patria y con él [con el sueldo] lo podré retener sin pedir otro a quien de nuevo sea menester enseñe». La primera traza (Fig. 28) muestra el gracioso alzado, muy flamenco, muy escurialense y la planta, no sólo de la torre, sino del «lugar que se á de atrincherar para hazerla y el alojamiento en galerías para 500 soldados q[ue] lo [h]an de guardar hasta q[ue] se haga». En la misma carta, Cristóbal Lechuga pone de manifiesto que tanto esta traza como la «de uer [ver] las camas que caben» las hace su criado Luis de Miquiñón, natural de «Graueligas» (actual Gravelines, Francia), que siempre ayudó a los ingenieros y a él mismo.

Entrañable resulta, sin duda,

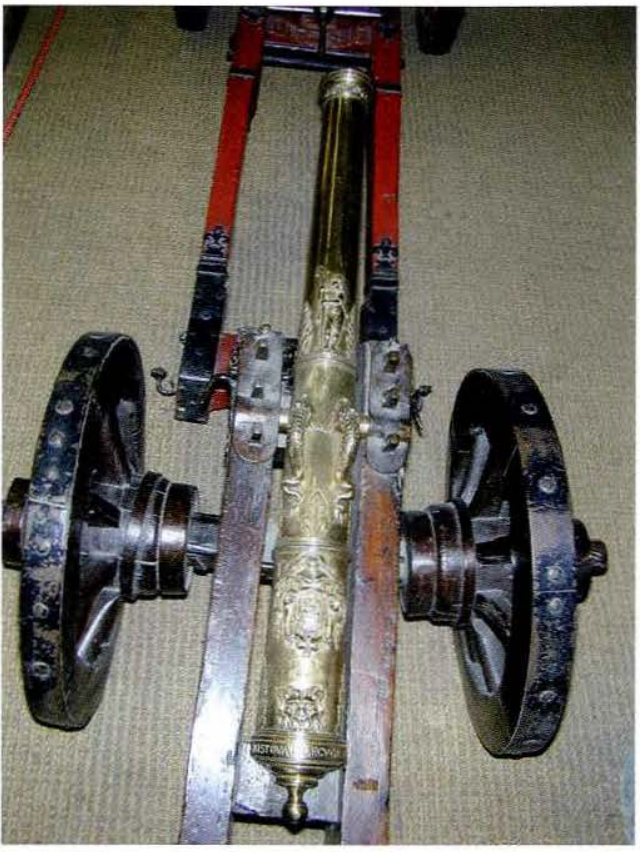

Fig. 29: Modelo de cañón con la leyenda en la faja de la culata «Cristóbal Lechuga me desinó». Museo del Ejército de Madrid (MEM) n. ${ }^{\circ}$ 4628. Fotografía de D. Francisco Javier López-Martín. no sólo el empleo del santo titular de Lechuga para designar la torre y el través San Cristóbal de La Mamora, sino que en su etapa como teniente general de la artillería en el ducado de Milán hizo fundir cañones y modelos en miniatura de los mismos, en alguno de los cuales viene representado el santo. Bellísimo es el caso del ejemplar del Museo del Ejército (MEM-4628) en cuya faja figura la inscripción «Cristóbal Lechuga me desinó»; más arriba, entre ésta y el primer refuerzo vemos representada la cabeza de un león entre cuyas fauces está el fogón del arma; un poco más arriba, el escudo del militar con sus características cinco lechugas en aspa; por último, sobre el tercer refuerzo, un relieve de san Cristóbal cruzando el río con el Niño Jesús sobre los hombros y su cayado florecido (Figs. 29 y $30)^{86}$. Dicho escudo del gobernador de La Mamora, así como la inscripción «Cristóbal

86 Sobre el estudio de estos modelos de cañones de fundición consultar LÓPEZ-MARTÍN, Francisco Javier, Historical and Technological Evolution of Artillery From its EarliestWidespread Use Until The Emergence of Mass-Production Techniques, a thesis presented in the Sir John Cass Dept. of Art, Media \& Design, for the degree of Ph.D., London Metropolitan University, Tesis Doctoral leída el 17 de septiembre de 2007, págs. 58 y 219. 


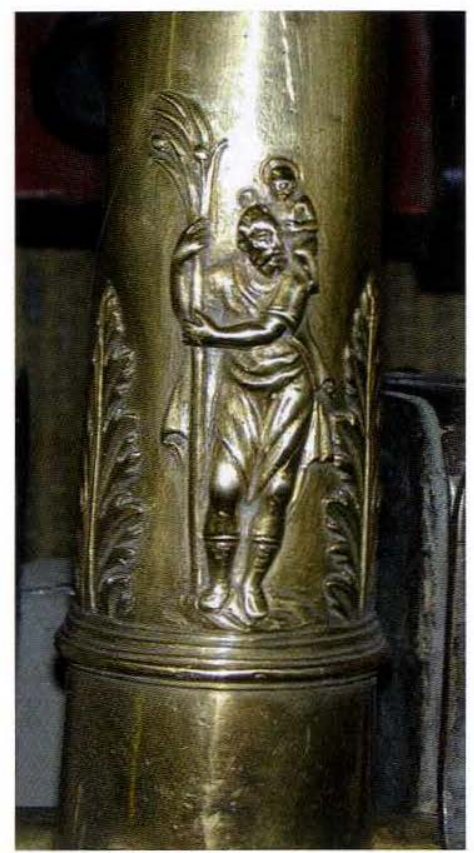

Fig. 30: Detalle del modelo anterior (MEM-4628) que muestra un relieve de San Cristóbal cruzando el río con el Niño Jesús sobre los hombros.

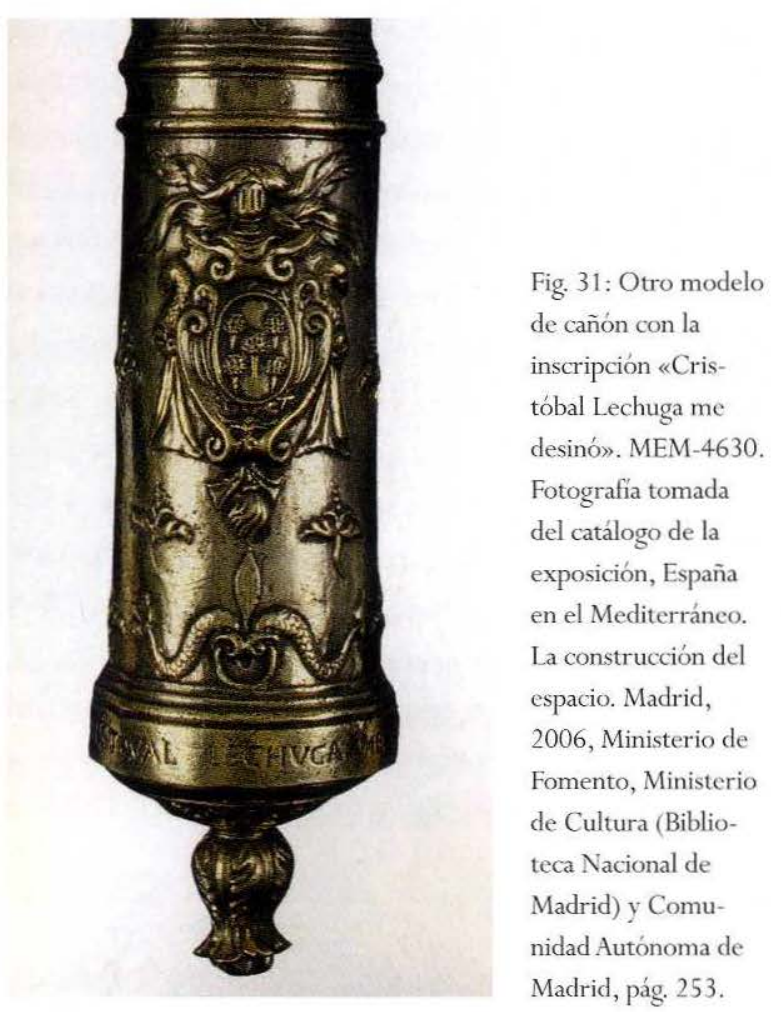

Lechuga me desinó» en la faja de la culata la encontramos también en el modelo 4630 del Museo del Ejército (Fig. 31).

En la actualidad se conserva bastante bien el contorno de la fortificación (Fig. 27). En el reducto junto al río, hoy sin la techumbre, la presencia española ha dejado su impronta en la clave del arco de la puerta de entrada con esa ménsula de corte clásico (Fig. 32). Desde dentro del mismo se obtiene una magnífica vista de todo el frente de la marina de la fortificación (Fig. 33) ${ }^{87}$. En la época del Protectorado español aún se podía apreciar como el reducto mantiene la cubierta (Fig. 34).

87. Estas fotografías fueron obtenidas en noviembre de 2005 durante el transcurso de un viaje que el autor hizo a Larache y La Mamora en compañia del Doctor Shinichi TAKAYANAGI, Doctor por la Universidad de Tokio con la Tesis Doctoral «Actividades y profesión de los ingenieros militares en la segunda mitad del siglo XVI; consideraciones sobre la carrera de Cristóbal de Rojas (1555?-1614)», 2005, Universidad de Tokio. 


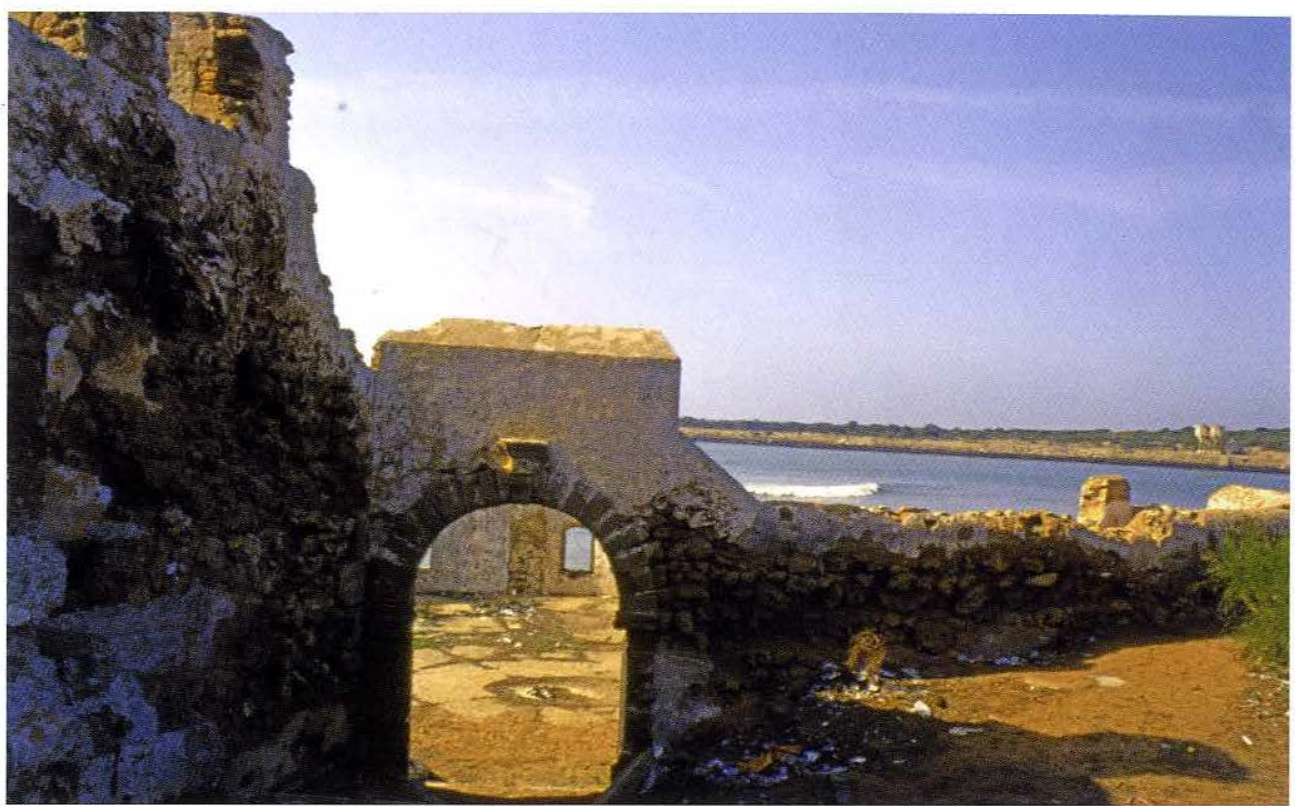

Fig. 32: Reducto circular junto a la playa. Ménsula de corte clasicista en la clave del arco de la puerta de entrada al mismo. Fotografía del autor.

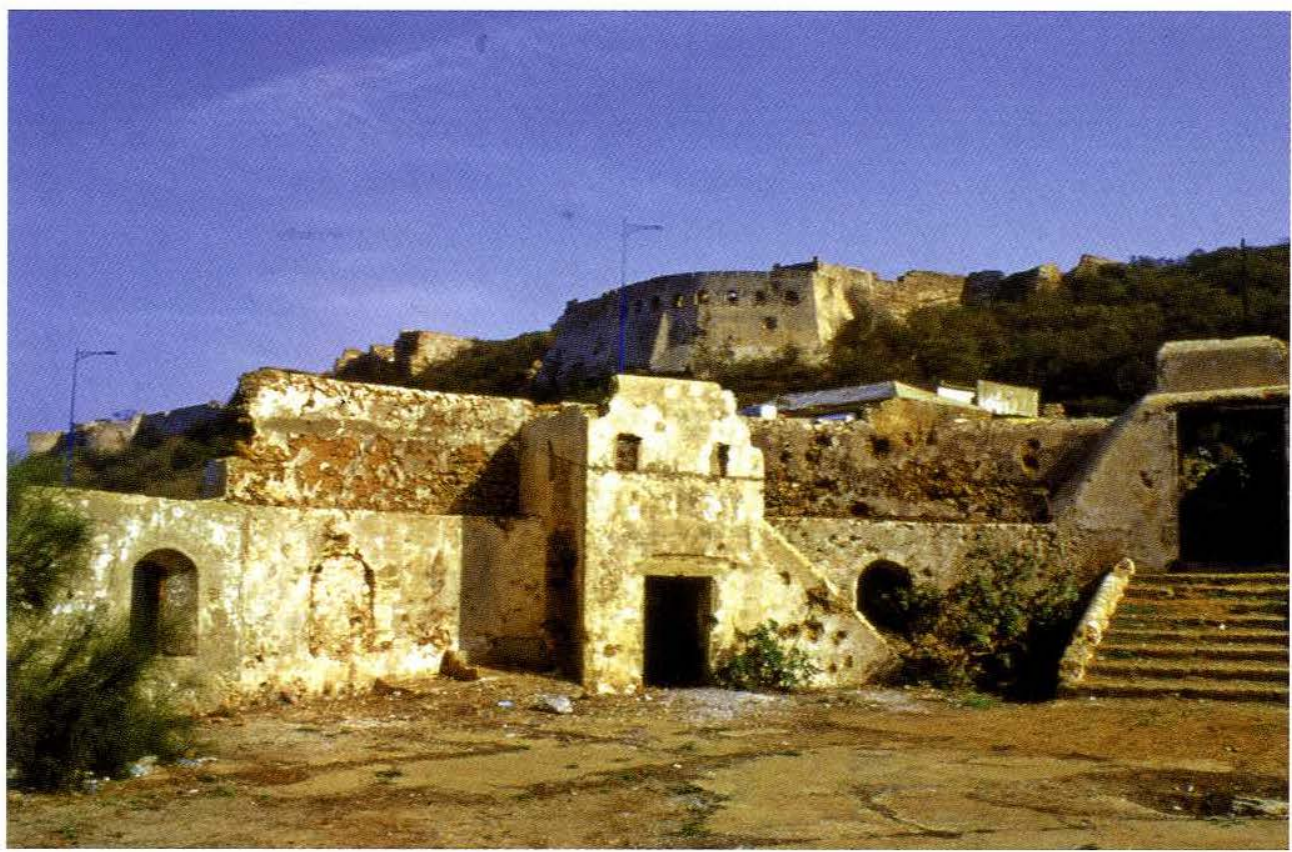

Fig. 33: Vista del frente de la marina de la fortificación de La Mamora desde el reducto circular de la playa. Fotografía del autor. 


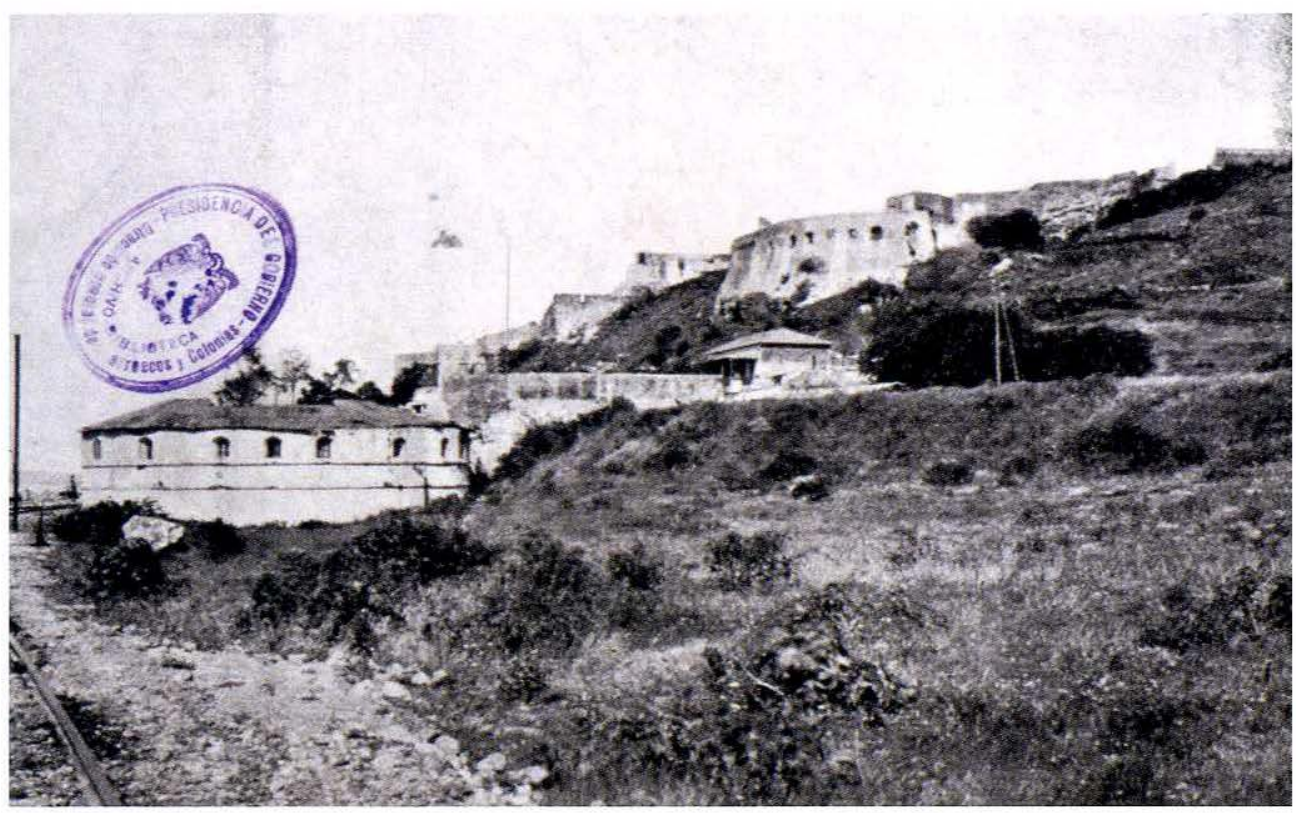

Fig. 34: El reducto circular junto a la playa en la época del Protectorado Español, cuando aun conservaba la cubierta. Tomada de GUASTAVINO GALLENT, Guillermo, La toma de La Mamora relatada por Tirso de Molina, Instituto General Franco para la investigación hispano-árabe, Larache, 1939.

El baluarte San Leonardo es el único que se conserva completo en la actualidad. Muy interesante resulta la observación de que la cortina entre el medio baluarte San Francisco y el baluarte San Leonardo ha sido desplazada hacia el exterior, con la circunstancia de que la muralla ha llegado a obstruir casi por completo una de las casamatas del baluarte San Leonardo ${ }^{88}$.

Quiero poner punto final a este artículo dando noticia del fallecimiento del gran artillero, ingeniero y tratadista, fundamental para la arquitectura militar del reinado de Felipe III ${ }^{89}$. Cristóbal Lechuga, como muchos de sus contemporáneos, pa-

88. Samir RAOUI lo puso de manifiesto en su brillante ponencia «San Miguel de Ultramar, une fortification espagnole au coeur de l'Atlantique», en el II Congreso Internacional Ciudad y Patrimonio: Muralla y Ciudad en el ámbito norteafricano, Melilla, 8 y 9 de octubre de 2007.

89. Ya en el siglo XVIII, el gran historiador militar Vicente de los Ríos afirma que «Fue Christoval Lechuga natural de Baeza, y como tal lo refiere entre los Varones Insignes de Andalucía el Padre Murillo. Tenía cincuenta y cuatro años cuando dio a luz su Discurso de Artillería en 1611; y aun- 
decía del temible mal de la gota. En agosto de 1620, sintiéndose muy enfermo hizo testamento, que ratificaría el 10 del mismo mes del año siguiente, dos días antes de su muerte.

El 20 de agosto de 1621, la recién enviudada doña María Lechuga -sobrina carnal, asimismo, del gobernador de La Mamora- escribe al rey en estos términos: «En doçe de este fue Dios seruido de llevarse para Sí a el maestro de campo Xpf [Xristophorvs] Lechuga, mi marido, en siete días de calenturas» ${ }^{90}$. En otra carta de la misma data, Rodrigo Lechuga, primo hermano del gobernador dice: «A doçe de este murió el maestro de campo Xpoual Lechuga, mi primo, gobernador de estas fuerças. Murió priuado de los çinco sentidos y las tres potencias del alma» ${ }^{91}$. Por su parte, el capitán Luis Coscón -sustituto provisional de Lechuga al mando de la fuerza-se dirige al monarca con las siguientes palabras: «Por la muerte del maestro de campo Lechuga, ha quedado a mi cargo el suplicar a V. Mag fauorezca a su mujer ymbiándole embarcaçion en q[ue] pueda yr a España con siguridad, pues sería cossa lastimossa q[ue] tras tan gran pérdida como [h]a sido la de su marido, auenture su persona. Suplico a VMag ${ }^{d}$ honrre en esta ocasión los seruiçios del maestro de campo Xpl Lechuga, pues siempre fue tan zeloso del seru ${ }^{\circ}$ servicio] de V Mag ${ }^{d}$.

Como un pequeño homenaje al gran militar Baezano, transcribo el fragmento de la lapida conmemorativa que nos ha quedado, que originalmente debió de permanecer en La Mamora: «EL MAESTRO [falta la palabra] DE CAMPO CRISTÓBAL LECHUGA, NATURAL DE LA CIUDAD DE BAEZA, UNO DE LOS GANADORES DE ESTE PUERTOY SITIOS» (Fig. 35).

que se ignora el año de su muerte, es creíble que no sobrevivió mucho á la publicación de esta obra, donde asegura estaban ya rendidas sus fuerzas con los continuos trabajos de la Guerra, que siguió desde la edad de 17 años», Vid. RÍOS, Vicente de los, Discurso sobre los ilustres autores, é, inventores de artilleria, que han florecido en España, desde los Reyes Catholicos hasta el presente, imprenta de Joachin Ibarra, calle de la Gorguera, Madrid, 1767, pág. 72. Erró Ríos nada menos que en diez años la supervivencia del militar baezano. A los historiadores posteriores a Vicente de los Ríos no les ha sido posible tampoco la constatación documental ni de la fecha ni del lugar donde murió. Por esas carambolas del destino con que a los investigadores a veces nos favorece, he tenido el privilegio de encontrar en el Archivo General de Simancas, hace algunos años, una y otro.

90. AGS, Guerra Antigua, leg. 866, s. fol. Carta de doña María Lechuga al rey. La Mamora, a 20 de agosto de 1621 .

91. AGS, Guerra Antigua, leg. 866, s. fol. Carta de Rodrigo Lechuga a Felipe III. La Mamora, a 20 de agosto de 1621 . 


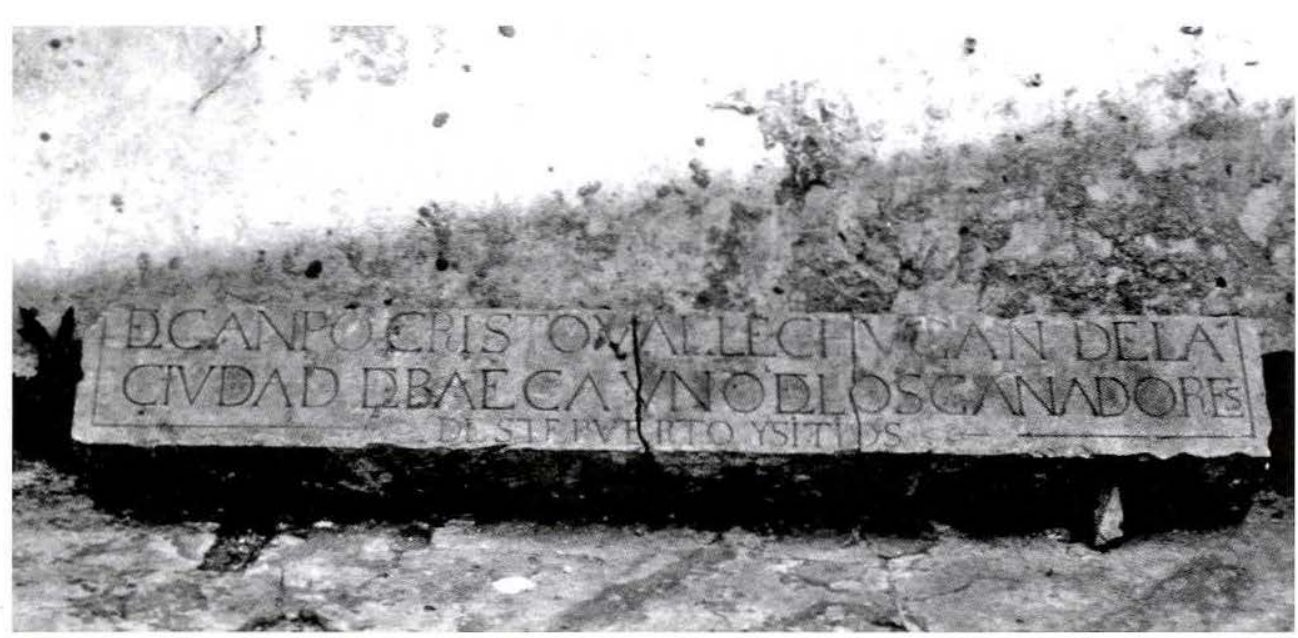

Fig. 35: Lápida conmemorativa de la ocupación de La Mámora: “de campo Cristóbal Lechuga, natural de ciudad de Baeza, uno de los ganadores de este puesto y sitios”.

Deseo terminar con una frase del conde de Fuentes, gobernador del Estado del Milán, en carta dirigida a Felipe III en 1604 proponiendo la construcción de ciudadelas en Cremona, Alejandría, Novara y Pavía. Dice Fuentes: «Pues aora hay tan buena ocasión [de hacerlas] estando aquí el capitán Lechuga, que es para esto [materia de fortificación] de los hombres más inteligentes de la nación y de mayor servicio». 